Research article

\title{
Utilization of centrate from urban wastewater plants for the production of Scenedesmus sp. in a raceway-simulating reactor
}

\author{
Ahlem Jebali a, b, F. Gabriel Acién ${ }^{\text {b }}$, Sami Sayadi a , Emilio Molina-Grima ${ }^{\text {b, * }}$ \\ a Laboratory of Environmental Bioprocesses, Sfax Centre of Biotechnology, University of Sfax, P.O. Box 1177, 3018 Sfax, Tunisia \\ ${ }^{\text {b } C h e m i c a l ~ E n g i n e e r i n g ~ D e p a r t m e n t, ~ U n i v e r s i t y ~ o f ~ A l m e r i ́ a, ~} 04120$ Almería, Spain
}

\section{A R T I C L E I N F O}

\section{Article history:}

Received 10 August 2017

Received in revised form

12 November 2017

Accepted 15 January 2018

\section{Keywords:}

Microalgae

Centrate

Productivity

Nutrient removal

Biochemical composition

\begin{abstract}
A B S T R A C T
This work investigates the production of the native microalgae strain Scenedesmus sp. in semi-continuous mode at lab scale in open raceway-simulating reactors and using centrate as the culture medium. The biomass productivity and nutrient removal capacity of Scenedesmus sp. at different dilution rates were investigated indoors as well as its tolerance to centrate as the culture medium at different concentrations. A biomass productivity of $7.80 \mathrm{~g} / \mathrm{m}^{2}$ day was obtained at $200 \mu \mathrm{E} / \mathrm{m}^{2} \mathrm{~s}, 5 \mathrm{~cm}$ culture depth, $0.301 /$ day of dilution rate and $60 \%$ centrate while nitrogen and phosphorus removal rates were $1.50 \mathrm{~g} / \mathrm{m}^{2}$ day and $0.15 \mathrm{~g} / \mathrm{m}^{2}$ day, respectively. The produced biomass characterization under these conditions showed a lipid content of $12.60 \% \mathrm{~d}$ wt. along with a favorable fatty acids profile with $57.70 \%$ of total fatty acids composed of saturated and monounsaturated fatty acids. Subsequently, the effect of light intensity and culture depth on biomass productivity and nutrient uptake as well as the biochemical composition and fatty acids profile was studied using two irradiance levels ( 200 and $1000 \mu \mathrm{E} / \mathrm{m}^{2} \mathrm{~s}$ ) and four culture depths $(5 \mathrm{~cm}, 10 \mathrm{~cm}, 15 \mathrm{~cm}$ and $20 \mathrm{~cm})$. Under optimal conditions of $1000 \mu \mathrm{E} / \mathrm{m}^{2} \mathrm{~s}, 60 \%$ centrate, $0.301 /$ day dilution rate and $15 \mathrm{~cm}$ culture depth, a maximum biomass productivity of $22.20 \mathrm{~g} / \mathrm{m}^{2}$ day was obtained. Nitrogen and phosphorus removal rates of $2.00 \mathrm{gN} / \mathrm{m}^{2}$ day and $0.40 \mathrm{gP} / \mathrm{m}^{2}$ day, respectively, were recorded. An amount of $11.70 \% \mathrm{~d}$ wt. of lipids was determined along with a suitable fatty acids profile for biofuel production.
\end{abstract}

(c) 2018 Elsevier Ltd. All rights reserved.

\section{Introduction}

Microalgae technology is attracting increased attention as a result of the development of renewable fuel production processes (Avagyan, 2008). At present, mass algal-based fuel commercialization is impeded due to the relatively low saponifiable lipid content of biomass feedstock as well as the techno-economic barriers and the viability concerns (Avagyan, 2017; Davis et al., 2016). These barriers are attributed to the high operation costs, due mainly to the use of fertilizers, energy and fresh water for the cultivation, which decreases the sustainability and competitiveness of microalgae-based technologies (Davis et al., 2016; Zhou et al., 2014; Zhu and Hiltunen, 2016). In fact, the current production cost range is about $5-10 € / \mathrm{kg}$ of microalgae biomass (Benemann, 2013), in which the use of freshwater, fertilizers and carbon dioxide account for $23-30 \%$ of the total (Davis et al., 2016; Zhou et al.,

\footnotetext{
* Corresponding author

E-mail address: emolina@ual.es (E. Molina-Grima).
}

2014). In order to effectively develop microalgae applications in low-value fields such as feed, biofertilizers and biofuels, the production cost needs to drop to $0.50 € / \mathrm{kg}$ (Borowitzka and Moheimani, 2010; Chisti, 2012) and even to $0.43 € / \mathrm{kg}$ in other studies (Davis et al., 2016).

Therefore, a coupled process combining waste treatment processes, particularly wastewater, to microalgae energy-rich biomass production could be an economically feasible option -microalgae cultivation in wastewater provides bioremediation while reducing the costs of algal feedstock production as well as effluent treatment (Avagyan, 2017, 2008). Indeed, wastewater algae-based treatment offers a promising route for an environmentally friendly technology (Avagyan, 2017).

Numerous studies have demonstrated that wastewater could fulfill the microalgae growth requirements for macro and micronutrients (Avagyan, 2017; Osundeko and Pittman, 2014). Microalgae can use a wide range of effluents (Avagyan, 2017). Centrate is one of the richest urban primary nutrient streams of nitrogen and phosphorus as well as of micronutrients; thus, it has been reported as potentially supporting microalgae growth (Morales-Amaral 
et al., 2015a, b; Osundeko and Pittman, 2014; Zhou et al., 2012a). However, at high centrate concentrations, the nitrogen content might be toxic for microalgae, particularly in the form of ammonium, at concentrations above $100 \mathrm{mg} / \mathrm{L}$ (Collos and Harrison, 2014; Ji et al., 2014; Morales-Amaral et al., 2015a); not to mention many other compounds such as phenols, organic pollutants, pesticides and heavy metals, which at high concentrations might also inhibit growth (Avagyan, 2017; Dong et al., 2014; Muñoz et al., 2006; Muñoz and Guieysse, 2006). However, Chlorella has high commercial productivity in such wastewater with their water dilution to the following contents: above total $\mathrm{N}(3 \mathrm{~g} / \mathrm{L}), \mathrm{NH}_{4}(1 \mathrm{~g} / \mathrm{L})$, chemical oxygen demand $\left(12 \mathrm{gO}_{2} / \mathrm{l}\right)$, and biological oxygen demand $\left(9 \mathrm{gO}_{2} / \mathrm{l}\right)$ (Avagyan, 2013, 2011).

One of the key criteria for wastewater-based algae production is the selection of a robust microalgae strain that can fully adapt to such a medium, and also provide high productivity and efficient nutrient removal. The genera Chlorella and Scenedesmus are the microalgal strains most frequently used in wastewater bioremediation (Tan et al., 2015; Min et al., 2011; Batista et al., 2015; Posadas et al., 2015). Additionally, selecting an appropriate strain that presents high robustness under the various uncontrollable environmental outdoor conditions (i.e. temperature, diurnal cycles and invasive microorganisms) is a crucial step in researching economically viable, microalgal-based centrate remediation. It has been previously demonstrated the robustness of the strain used in this study, which was cultivated in untreated primary urban wastewater, highly concentrated in nutrients, yet it achieved a maximum biomass productivity of $0.9 \mathrm{~g} / \mathrm{L}$ day at 0.61 /day under a light intensity of $800 \mu \mathrm{E} / \mathrm{m}^{2} \mathrm{~s}$ (Jebali et al., 2015).

Another key criterion is the selection of an appropriate reactor design for algae cultivation that ensures biomass production at a competitive cost for low-value products such as biofuel. Closed photobioreactors present high operation costs while open reactors, such as raceway reactors offer various advantages such as flexibility, low power consumption, simple construction and ease of operation (Acién Fernández et al., 2013; Chiaramonti et al., 2013; Rawat et al., 2013).

Nevertheless, there are problematic aspects to microalgal centrate treatment in open reactors that were poorly studied such the need for further research on the operational and environmental parameters effect.

Very few studies have researched in semi-continuously-fed cultures, the simultaneous influence of the dilution rate and centrate concentration as well as light intensity and culture depth effects on the performance of the microalgae strain in terms of productivity and nutrients removal capacity using centrate as the culture medium (Chinnasamy et al., 2010; Sepúlveda et al., 2015).

In the present study, the objective is to assess the production of microalgae using wastewater, and also contributing to recover nutrients from these effluents. To this end, indoors cultures of native Scenedesmus sp. were conducted in controlled conditions simulating those in real outdoor raceway reactors, and using mixtures of centrate and tap water as culture medium. Experiments were carried out in semi-continuous mode for the investigation of the simultaneous effect of dilution rate (0.04-0.40 1/day) and centrate concentration $(15,30,45$ and $60 \%$ of centrate) in order to determine the optimal combination of these two parameters for the strain's performance. It is worth noting that dilution rate is the inverse of the hydraulic retention time, the latter is the usual operational parameter used in wastewater treatment plants. Additionally, the light intensity at two levels (200 and $1000 \mu \mathrm{E} /$ $\left.\mathrm{m}^{2} \mathrm{~s}\right)$ and four culture depths $(5,10,15,20 \mathrm{~cm})$ were also tested at the same culture conditions. Biomass productivity, nutrients removal, as well as the biochemical composition and the saponifiable fatty acid content and profile of the produced microalgal biomass, were evaluated at steady state.

Addressing these issues is essential prior to large-scale outdoor commercial use of microalgae for centrate bioremediation and biomass production.

\section{Materials and methods}

\subsection{Microorganism and culture media}

The freshwater isolate Scenedesmus sp. was used for the study. This microalgae strain was selected in a previous work out of several microalgal strains potentially suitable for wastewater treatment, in which it was the top performer (Jebali et al., 2015). Culture inoculum was prepared under continuous illumination and aeration using MDM medium (Ichimura and Itoh, 1977). For the experiments, centrate from a real urban wastewater treatment plant of the city of Almería (Spain) was used as to prepare the culture medium. The centrate was obtained after separating the solids from the digestate liquid fraction resulting from the anaerobic digestion of activated sludge produced from the urban wastewater treatment. The centrate was stored in a cold room $\left(4^{\circ} \mathrm{C}\right)$ and then used in the subsequent experiments. Different experimental culture media were prepared, namely 15, 30, 45 and $60 \% \mathrm{v} / \mathrm{v}$, by mixing tap water with the centrate. The prepared medium was sterilized to remove contaminants and to investigate the performance and nutrient removal capacity of this strain as well as its tolerance to the centrate as the culture medium. Table 1 gives the average composition of the different collected centrate batches used.

\subsection{Experimental culture conditions}

Experiments were run indoors using four open reactors with circular bases and opaque PVC plastic walls (diameter: $25 \mathrm{~cm}$; height: $28 \mathrm{~cm}$; working volume: $10 \mathrm{~L}$; a volume to surface ratio $\mathrm{V} / \mathrm{S}$ : $0.2 \mathrm{~m}^{3} / \mathrm{m}^{2}$ ). The reactors were designed to mimic the culture conditions in real raceways ponds. To that end, agitation was ensured using magnetic agitators (IKA RH basic 2, Germany) with no air used for mixing. The $\mathrm{pH}$ was kept within the optimum range, 7.80-8.00, by on-demand $\mathrm{CO}_{2}$ injection at a flow rate of $0.01 \mathrm{v} / \mathrm{v} /$ $\mathrm{min}$. The temperature was kept constant at $25^{\circ} \mathrm{C}$ by controlling the room temperature. A set of $21 \mathrm{~W}$ daylight fluorescent tubes (Simon Brico Daylight T5), located horizontally above the reactors, was used to artificially illuminate the vessels, simulating the circadian cycle. The light intensity was measured by a $4 \pi$ quantum scalar irradiance sensor QSL-100 (Biospherical Instrument, San Diego, CA, USA).

To evaluate the performance of Scenedesmus sp., experiments were firstly conducted in batch mode for 6 days in the four reactors simultaneously with the four centrate dilutions in parallel, at a $5 \mathrm{~cm}$ culture depth and a $200 \mu \mathrm{E} \mathrm{m}^{-2} \mathrm{~s}^{-1}$ irradiance level, starting with an equal cell density of $1.4610^{7} \mathrm{cell} / \mathrm{mL}$. After this, the cultures were operated in semi-continuous mode by daily diluting the cultures at different dilution rates, from 0.04 to 0.401 /day. The second set of experiments were performed at two light intensity levels, with a maximum 200 and $1000 \mu \mathrm{E} / \mathrm{m}^{2} \mathrm{~s}^{-1}$ to investigate the effect of light intensity on biomass productivity and nutrient removal efficiency. The other culture conditions stayed the same.

Finally, the influence of different culture depths, namely 5, 10, 15 and $20 \mathrm{~cm}$, on biomass productivity and nutrient removal using the optimized culture conditions already determined (an irradiance intensity of $1000 \mu \mathrm{E} \mathrm{m}^{-2} \mathrm{~s}^{-1}, 60 \%$ centrate dilution and a dilution rate of 0.301 /day), was investigated.

All the experiments were operated in semi-continuous mode until steady state was achieved. Once the steady state biomass 
Table 1

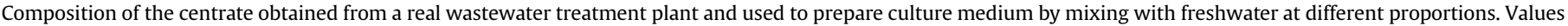
represented in each experiment are the average of four centrate batches.

\begin{tabular}{|c|c|c|c|}
\hline \multirow[t]{2}{*}{ Nutrient } & $\begin{array}{l}\text { Centrate used for dilution } \\
\text { rate selection experiment }\end{array}$ & $\begin{array}{l}\text { Centrate used for light intensity and centrate } \\
\text { percentage optimization experiment }\end{array}$ & $\begin{array}{l}\text { Centrate used for culture depth } \\
\text { selection experiment }\end{array}$ \\
\hline & \multicolumn{3}{|l|}{ Concentration, mg/L } \\
\hline $\mathrm{N}-\mathrm{NH}_{4}^{+}$ & $310.90 \pm 40.73$ & $318.74 \pm 2.75$ & $264.00 \pm 9.24$ \\
\hline $\mathrm{P}-\mathrm{PO}_{4}^{3-}$ & $119.64 \pm 82.08$ & $27.70 \pm 0.01$ & $20.40 \pm 0.45$ \\
\hline $\mathrm{N}-\mathrm{NO}_{3}^{-}$ & $13.22 \pm 4.12$ & $27.14 \pm 13.46$ & $5.46 \pm 1.78$ \\
\hline
\end{tabular}

concentration for each experiment was achieved, the culture was maintained operating in these conditions for a period of time during which the total harvested culture is twice equal to the culture volume.

\subsection{Determination of biomass concentration and fluorescence measurements}

Samples were taken daily to measure microalgae biomass by optical density at $750 \mathrm{~nm}$ using a spectrophotometer (ATI UNICAM UV/Vis Spectrometer UV2, Cambridge, UK). The dry weight biomass concentration was determined by filtrating $100 \mathrm{~mL}$ of culture through a pre-dried $1 \mu \mathrm{m}$ filter (Macherey-Nagel GmbH \&Co.KG, Germany) and drying it in an oven at $80^{\circ} \mathrm{C}$ for $24 \mathrm{~h}$. In addition, chlorophyll fluorescence, as $\mathrm{Fv} / \mathrm{Fm}$, was measured daily using a fluorometer (AquaPen AP 100, Photon Systems Instruments, Drasov, The Czech Republic) in order to check the cells' physiological status. Dissolved oxygen and temperature were measured daily (Hanna Instruments, HI98193, Romania). All the analyses were carried out in duplicate and the mean value was reported.

\subsection{Analytical procedure}

Nutrients analyses were performed at the reactors' inlet and outlet. A $50 \mathrm{~mL}$ culture sample was collected and filtrated using $1 \mu \mathrm{m}$ filters (Macherey-Nagel GmbH \&Co.KG, Germany); the filtrate was used for nutrient analysis. The phosphate was measured by visible spectrophotometry through the phospho-vanadomolybdate complex (Phosphate Standard for IC: 38364). The nitrate was quantified by measuring optical density at $220 \mathrm{~nm}$ and $275 \mathrm{~nm}$ (Nitrate Standard for IC: 74246). The ammonium was measured according to the Nessler method (Ammonium standard for IC: 59755).

At steady state, biomass was harvested by centrifugation at $7500 \mathrm{rpm}$ for 5 min (SIGMA 4-15 Sartorius, Goettingen, Germany), washed twice with distilled water, freeze dried and used to determine the biochemical composition. Protein content was quantified according to the modified Lowry method proposed by Herbert et al. (1971). Total lipids were determined as described by Kochert (1978). The fatty acids content and profile were obtained by direct transesterification and gas chromatography (Agilent Technologies 6890 N Series Gas Chromatograph, Santa Clara, CA, USA) as described by Rodríguez-Ruiz et al. (1998). Ash was determined by incinerating a $100 \mathrm{mg}$ sample in an oven at $450{ }^{\circ} \mathrm{C}$ for $48 \mathrm{~h}$. The carbohydrate content was estimated by subtracting the sum of the other fraction percentages (ash, lipids and proteins) from 100 . All of the analyses were carried out in duplicate and the mean value was reported.

\subsection{Mass transfer and mixing time}

The determination of the mass transfer coefficient $\left(\mathrm{K}_{\mathrm{La}}\right)$ and the mixing time was carried out to characterize the reactors. The $\mathrm{K}_{\mathrm{La}}$ experiment was conducted as described by Mendoza et al. (2013b). The variation in dissolved oxygen (DO) overtime was assumed to be a function of the mass transfer coefficient $\left(\mathrm{K}_{\mathrm{La}}\right)$ and the driving force $\left(\left[\mathrm{O}_{2}{ }^{*}\right]-\left[\mathrm{O}_{2}\right]\right)$ according to equation (1):

$\frac{d\left[O_{2}\right]}{d t}=K_{L a} \cdot\left(\left[O_{2}^{*}\right]-\left[O_{2}\right]\right)$

where $\mathrm{K}_{\mathrm{La}}$ is the mass transfer coefficient $\left(\mathrm{s}^{-1}\right),\left[\mathrm{O}_{2}\right]$ is the DO concentration $\left(\mathrm{mg} \mathrm{l}^{-1}\right),\left[\mathrm{O}_{2}{ }^{*}\right]$ is the equilibrium DO concentration $\left(\mathrm{mg} \mathrm{l}^{-1}\right)$ and $\mathrm{t}$ is time $(\mathrm{s})$. The integration of this equation between time zero and time $t$, the mass transfer coefficient, can be obtained by (Eq. (2)) (Chisti, 1999):

$K_{L a}=\frac{\ln \left(\left(\frac{\left[O_{2}^{*}\right]-\left[O_{2}\right]_{t=0}}{\left[O_{2}^{*}\right]-\left[O_{2}\right]}\right)\right)}{t}$

For mixing time determination, the experiment was conducted by adding pulses of saturated sodium hydroxide under the same culture conditions; the variation in $\mathrm{pH}$ was then recorded. Mixing time was defined as the time required for variations in $\mathrm{pH}$ to reach a final stable value. The software acquisition data used was StudioData.

\section{Results}

To evaluate the performance and robustness of the native microalgae strain Scenedesmus sp. to centrate, different tap water and centrate mixtures were prepared and different dilution rates were applied (from 0.041 /day to 0.401 /day) using a culture depth of $5 \mathrm{~cm}$. Based on the literature reviews (Morales-Amaral et al., 2015a, b; Sepúlveda et al., 2015), a range of centrate concentrations $(15 \%, 30 \%, 45 \%$ and $60 \%$ centrate $\mathrm{v} / \mathrm{v})$ were investigated. Table 1 shows the average composition of the centrate used for the experiments. The phosphorus concentration varied between 20.40 and $119.60 \mathrm{mg} / \mathrm{L}$. The $\mathrm{N}_{-} \mathrm{NH}_{4}^{+}$content was in the $264.00-318.74 \mathrm{mg} /$ $L$ range. Variations in nutrient concentration of the centrate were related to the operational conditions of the urban wastewater treatment plant, and real centrate was used in this study to know the existence of these variations in order to confirm the reliability of whatever system using this type of effluents.

The characteristics of the centrate indicate that it could adequately provide most of the essential nutrients for algal growth, as previously reported by several authors (Morales-Amaral et al., 2015a, b; Osundeko and Pittman, 2014; Zhou et al., 2012a). In fact, using centrate as the sole nutrient source for microalgae biomass production offers dual returns: (1) to substitute the use of non-sustainable and expensive fertilizers, which are considered a burden in a mass algal production system and (2) to treat this type of residue and produce microalgae biomass that could be used for a range of low cost applications. At present, centrate is recycled in wastewater treatment plant by sending it to the head of the process for depuration; this makes the whole process more costly and energy consuming. 
Additionally, the gas-liquid mass transfer capacity and the fluid dynamic within the reactor used were characterized. The mass transfer and mixing time determined were $4.72 \mathrm{~h}^{-1}$ and $13 \mathrm{~s}$, respectively. Microscopic observations of the different cultures tested were performed during the experiment and showed no contamination by other microalgae strains.

\subsection{Optimization of the dilution rate and centrate concentration}

Fig. 1 depicts the biomass concentration, productivity and fluorescence of chlorophylls ( Fv/Fm) variation during the experiment as a function of the dilution rate for the various centrate percentages used. The results demonstrated a typical variation in the dilution rate for light-limited cultures, in which the biomass concentration decreases as the dilution rate increases. The biomass concentration increased with the centrate concentration (Fig. 1A). The biomass productivities, in terms of volumetric and areal productivity, were in the $0.04-0.16 \mathrm{~g} / \mathrm{L}$ day and $2.10-7.80 \mathrm{~g} / \mathrm{m}^{2}$ day range, respectively (Fig. 1B). It is worth noting that ash content was ranging from 3 to $12 \% \mathrm{~d} w \mathrm{wt}$.

The highest biomass productivity obtained under the conditions of $200 \mu \mathrm{E} / \mathrm{m}^{2} \mathrm{~s}$ and $5 \mathrm{~cm}$ culture depth $\left(7.80 \mathrm{~g} / \mathrm{m}^{2}\right.$ day $)$ was obtained at 0.30 day $^{-1}$ and for a $60 \%$ centrate dilution. Thus, this dilution rate was selected for further experiments.

The physiological status of the cells was checked daily during the experiment and the data at steady state are displayed in Fig. 1C. The results show that the Fv/Fm remained almost constant for the first three dilution rates and centrate levels; except at $0.40 \mathrm{day}^{-1}$, where a decrease was noticed for all the centrate dilutions used. It is worth noting that at $60 \%$ centrate, the Fv/Fm was up to the 0.65-0.69 range, which illustrates this strain's considerable tolerance to such a high centrate concentration compared to some strains in other studies.

The biochemical composition of the biomass was evaluated at steady state and the data are shown in Fig. 2. The results revealed that the carbohydrate content presented the main biomass fraction at the different dilution rates and centrate levels tested (Fig. 2A). The carbohydrate content varied from 49.00 to $59.80 \%$ (DW) with no significant influence from the dilution rate or centrate concentration being noticed. Regarding protein content, values varied with no direct relationship being observed to the dilution rate (Fig. 2B).

As regards lipid content, a decrease was noticed in the lipid fraction as the dilution rate increased for $15 \%$ and $30 \%$; whereas for 45 and $60 \%$, this tendency was not observed (Fig. 2C). The analysis of fatty acid content and the lipid fraction profile for the different dilution rates and centrate concentrations tested was conducted at steady state. The results are summarized in Table 2. For the same centrate concentration, the fatty acid content decreased as the dilution rate increased, except at $0.401 /$ day. For the different dilution rates and centrate levels, the fatty acid profile was mainly composed of short-chain fatty acids; namely, C16:0, C18:3n3, C 18:0, C18:1n9, C16:3n 4 and $C 16: 3 n 4$. There was a predominance of C16:0 where the total fatty acid values ranged from 20.50 to $14.50 \%$, while a considerable amount of C 18:0 (7.20-11.20\% of total fatty acids) was also observed. Furthermore, a significant amount of $\mathrm{C} 18: 2 \mathrm{n} 6$ at $0.04,0.14$ and 0.401 /day was determined although this fatty acid was not detected at $0.301 /$ day.

In the present study, nutrient removal analyses were conducted at steady state. Fig. S1 (supplementary materials) represents the nitrogen removal efficiency with the centrate percentage tested and the dilution rate applied. The variations of $\mathrm{N}_{-} \mathrm{NH}_{4}^{+}$at the inlet and outlet streams are presented in Fig. S1 in supplementary material. The highest $\mathrm{N}-\mathrm{NH}_{4}^{+}$depuration (97.00\%) was obtained at 0.04 1 /day and $45 \%$ centrate whereas the lowest $(25.80 \%$ ) was at 0.401 / day and $15 \%$ centrate.
For a fair comparison of the strains and reactor systems used, the recommendable parameter to study carefully in nutrient analysis data is the removal rate capacity determined in continuous mode since depuration is simply a function of the initial nutrient concentration supplied. Indeed, it is often claimed that working in continuous mode offers tighter control and a more accurate idea concerning the optimal combination of operational parameters to be employed prior to actual commercial microalgae production.

Fig. 3A displays the nitrogen removal rates as a function of the dilution rate and the different centrate mixtures tested. The results demonstrate that, for all the assays, the removal rates were lower, the lower the centrate dilution tested, and increased when the applied dilution rate increased-this correlates positively to the biomass productivity data since maximal productivities were achieved at high centrate percentages ( 45 and 60\%) and dilution rates (0.30-0.40 1/day). The highest removal capacity was obtained at $0.401 /$ day and $60 \%$ centrate while the lowest was at 0.041 /day and
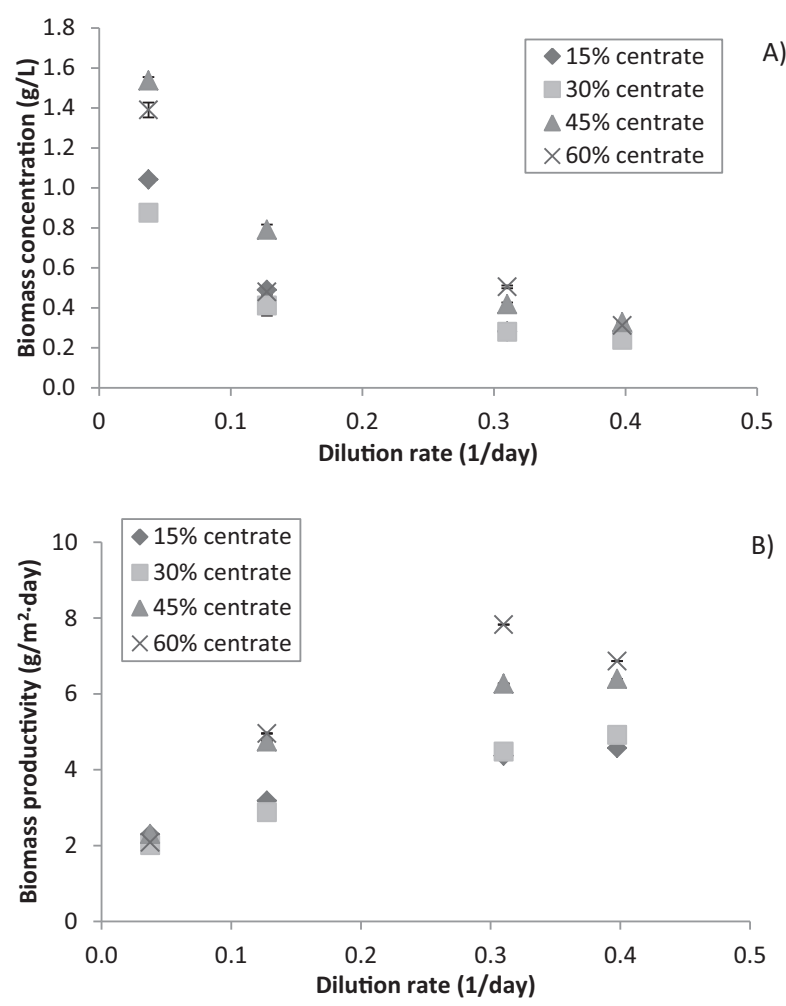

B)

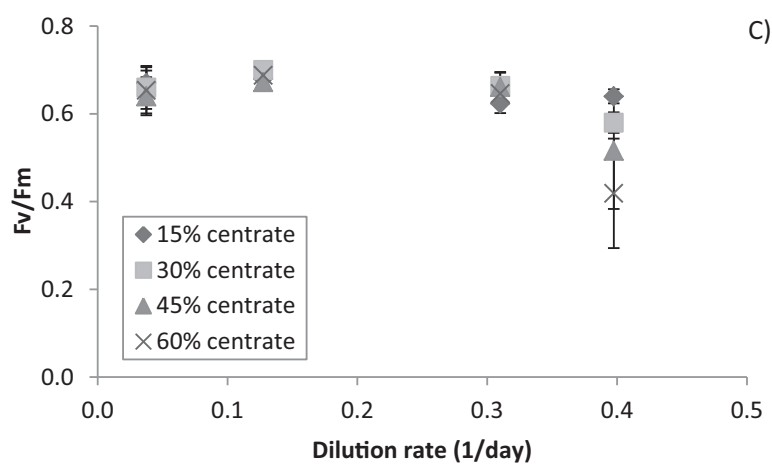

Fig. 1. Variations in biomass concentrations (A), productivities (B) and photosynthetic activities $\mathrm{Fv} / \mathrm{Fm}(\mathrm{C})$, at steady state for the different centrate concentrations used as a function of the dilution rate. Maximum impinging irradiance $200 \mu \mathrm{Em}^{-2} \mathrm{~s}^{-1}$. Data values are means $( \pm \mathrm{SE})$ of duplicate samples. 

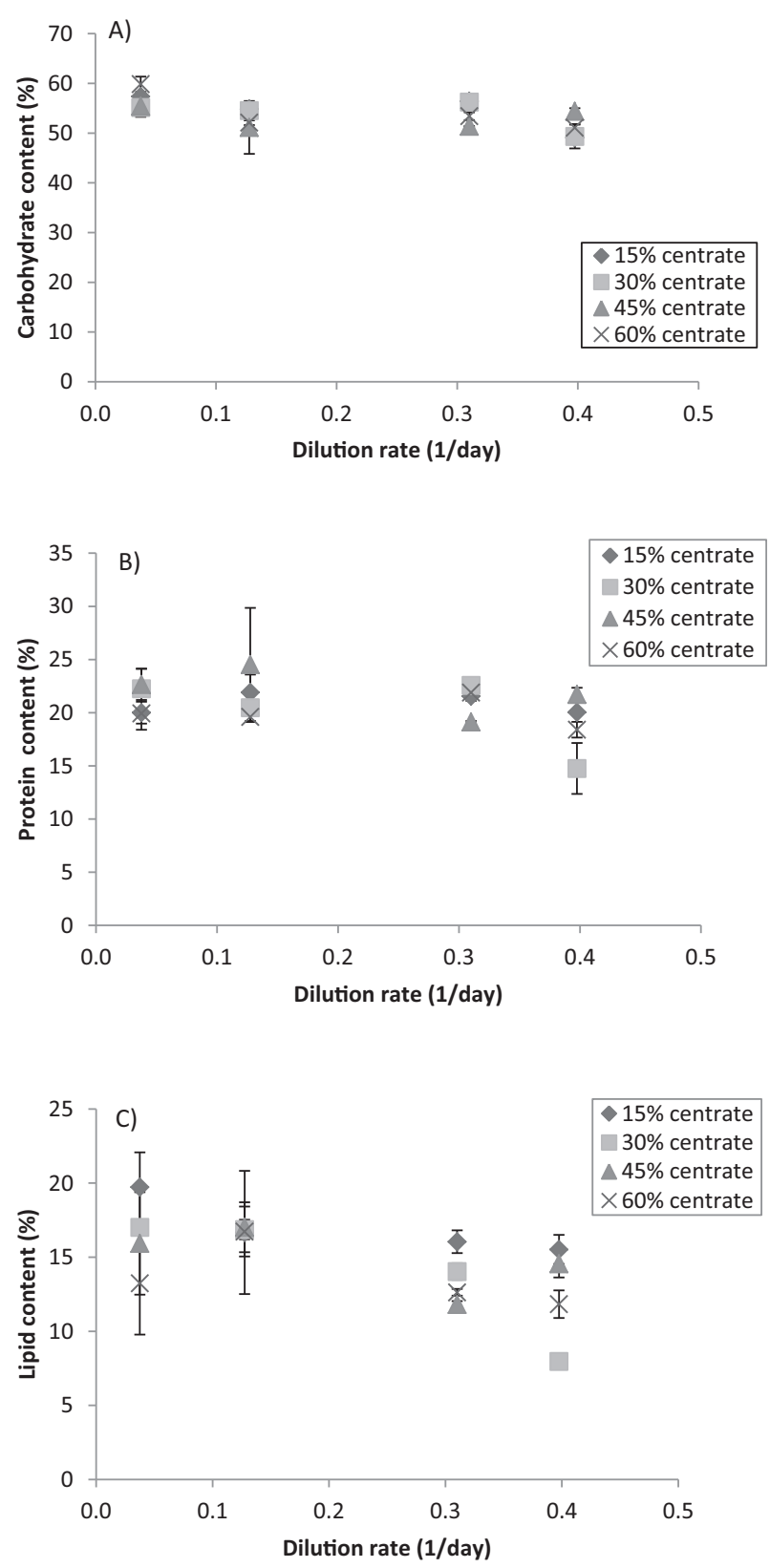

Fig. 2. Biochemical composition of Scenedesmus sp. at steady state as a function of different centrate concentrations and dilution rates: (A) lipid content, (B) protein content and (C) carbohydrate content. Maximum impinging irradiance, $200 \mu \mathrm{E} \mathrm{m}^{-2} \mathrm{~s}^{-1}$.

\section{$15 \%$ centrate.}

Phosphorus is another primary nutrient that plays a significant role in microalgae cell growth and metabolism. With respect to phosphorus elimination, analyses at steady state were performed. Variations in $\mathrm{P}_{-} \mathrm{PO}_{4}^{3-}$ concentrations at the inlet and outlet streams are shown in Fig. S2 (supplementary materials). The results show a variable trend as well as low phosphorus depuration from the different centrate mixtures used, in which no direct relationship was observed between phosphorus depuration, centrate concentration and dilution rate. Additionally, the $\mathrm{P}_{-} \mathrm{PO}_{4}^{3-}$ outlet concentrations were always high in all the assays, and nearly equal to those at the inlet, except at low dilution rates where the elimination efficiency was higher (relatively)-probably due to the high retention time. In fact, the highest phosphorus depuration percentage (58.05\%) was reached at 0.041 /day and 30\% centrate.
The data regarding nitrogen removal rates for the centrate percentage tested and the dilution rate applied are depicted in Fig. 3B. Similar to the nitrogen results, the removal capacity increased as the dilution rate increased, and high values were obtained at high centrate percentages. The highest removal rate was recorded for 30 and $60 \%$ centrate at 0.401 /day.

\subsection{Optimization of light intensity and culture depth}

The centrate compositions used in these two sets of experiments are listed in Table 1.

\subsubsection{Optimization of light intensity}

The effect of light intensity on biomass productivity and photosynthetic efficiency for the various experiments performed in semi-continuous mode at $0.30 \mathrm{day}^{-1}$, and using different centrate concentrations, is illustrated in Fig. 4. Results revealed that, for each light intensity level tested, the biomass productivity obviously improved as the centrate dilution increased. The highest biomass productivity $\left(15.90 \mathrm{~g} / \mathrm{m}^{2}\right.$ day corresponding to $0.30 \mathrm{~g} / \mathrm{L}$ day) was determined under a light intensity of $1000 \mu \mathrm{E} / \mathrm{m}^{2} \mathrm{~s}$, a $5 \mathrm{~cm}$ culture depth and a centrate dilution of $60 \%$; this is more than twice the productivity $\left(7.80 \mathrm{~g} / \mathrm{m}^{2}\right.$ day) obtained under the same conditions with alight intensity of $200 \mu \mathrm{E} / \mathrm{m}^{2} \mathrm{~s}$.

The photosynthetic activity measured as Fv/Fm data is depicted in Fig. 4B. The values did not show any stress on the cultures at the different centrate concentrations applied. At $60 \%$ centrate dilution, the ammonium concentration reached $230.00 \mathrm{mg} / \mathrm{L}$; nevertheless, no stress was observed caused by the different media used and the strain fully adapted to it while the centrate sufficiently supported microalgae growth.

The harvested biomass was also characterized at steady state and the results are shown in Fig. 5. The protein content was lower, the higher the light intensity that was applied; this was the case for all the centrate concentrations tested (Fig. 5B). In contrast, the carbohydrate contents followed an opposite trend, increasing as the light intensity increased (Fig. 5C).

Similarly, the effect of light on lipid content was noticeable, in that the total lipid content was promoted by a decrease of light intensity for all the centrate dilutions tested (Fig. 5A). The highest lipid amount was recorded at a $15 \%$ centrate dilution and $200 \mu \mathrm{E} /$ $\mathrm{m}^{2} \mathrm{~s}(16.0 \%)$. At a $60 \%$ centrate dilution and $1000 \mu \mathrm{E} / \mathrm{m}^{2} \mathrm{~s}$, it was $10.5 \%$ with a lipid productivity of $33.30 \mathrm{mg} / \mathrm{L}$ day (or $1.66 \mathrm{~g} / \mathrm{m}^{2}$ day); these correspond to the conditions for highest biomass productivity.

Regarding the fatty acid content, its data and profile are given in Table 3. The content ranged from 2.90 to $4.90 \% \mathrm{~d}$ wt with light having no clear effect, whereas the fatty acid profile showed a slightly higher saturated and unsaturated fatty acid content under low light compared to high light, that showed a slight increase content in polyunsaturated fatty acids (C16:3-C18:3). However, a favorable fatty acid profile for C16-C18 (51.80\% of total fatty acids) was observed at a $60 \%$ centrate dilution and $1000 \mu \mathrm{E} / \mathrm{m}^{2} \mathrm{~s}-$ the optimal conditions for biomass productivity.

The influence of light irradiance on ammonium depuration and nitrogen removal rates at the optimal dilution rate $\left(0.30\right.$ day $\left.^{-1}\right)$ was determined. The results show that ammonium depuration was higher, the higher the irradiance (except at the 30\% centrate level), which correlates with the biomass productivity data (Fig. S3A, supplementary materials). At low irradiance, the nitrogen removal rates increased as centrate concentration increased but a further increase in centrate concentration from 45 to $60 \%$ did not promote a nitrogen removal rate increase (Fig. 6A). At high irradiance, the nitrogen removal rates increased consistently with the ascending centrate concentration to reach a high value of $2 \mathrm{~g} / \mathrm{m}^{2}$ day 


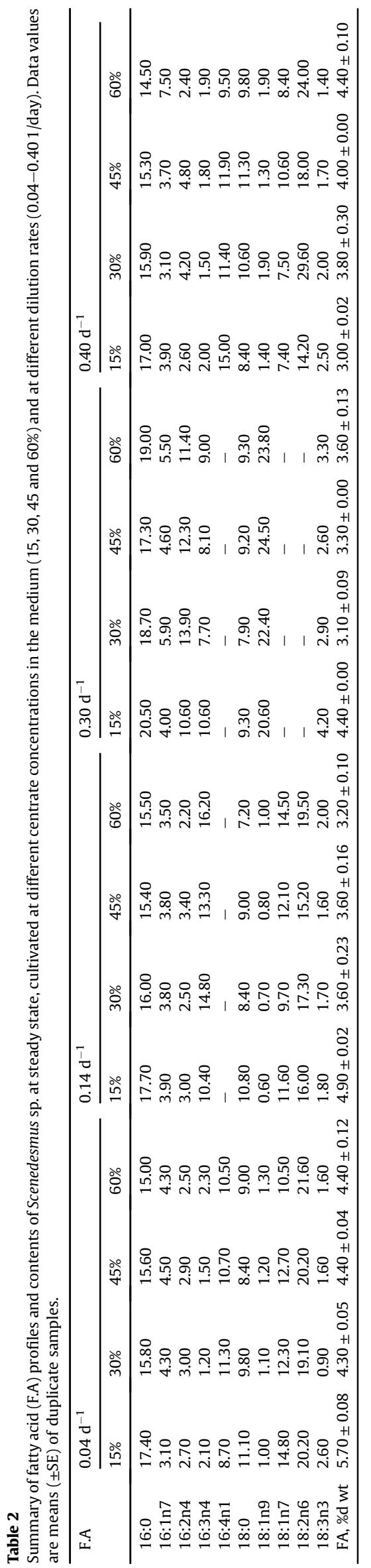

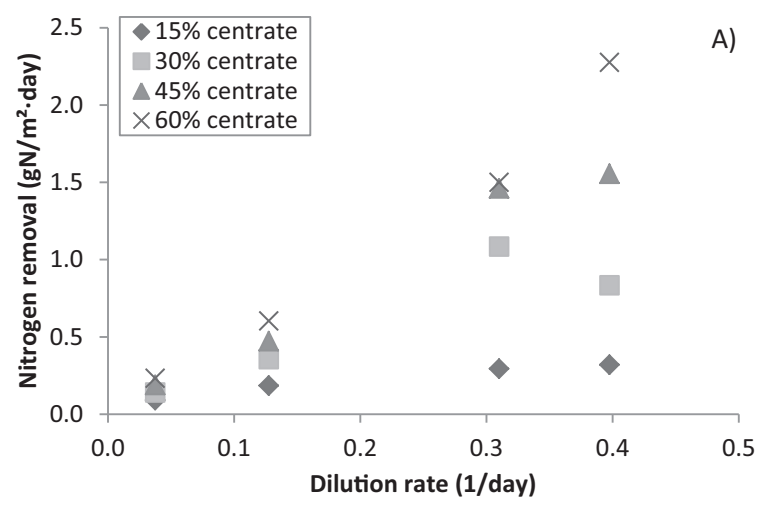

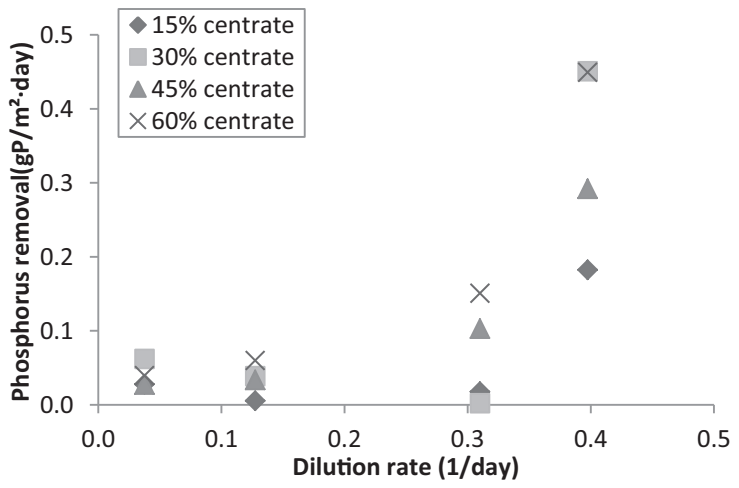

Fig. 3. Nitrogen (A) and phosphorus (B) removal rates determined at steady state for the different centrate concentrations used as a function of the dilution rate. Culture performance in semi-continuous mode. Maximum impinging irradiance, $200 \mu \mathrm{E}$ $\mathrm{m}^{-2} \mathrm{~s}^{-1}$.

corresponding to $39.90 \mathrm{mg} \mathrm{N} / \mathrm{L}$ day (for $60 \%$ centrate and $1000 \mu \mathrm{E} /$ $\mathrm{m}^{2} \mathrm{~s}$ irradiance).

Regarding phosphorus removal, the analysis data performed at steady state are presented in Fig. 6B. The phosphorus removal efficiencies varied with media composition and light intensity - at the upper irradiance level, these were greater, the higher the centrate concentration (Fig. S3B, supplementary materials). The highest P$\mathrm{PO}_{4}^{3-}$ removal efficiency was only (52.50\%) at $1000 \mu \mathrm{E} / \mathrm{m}^{2} \mathrm{~s}$ for an initial $\mathrm{P}_{-} \mathrm{PO}_{4}^{3-}$ concentration of $17.10 \mathrm{mg} / \mathrm{L}$ (60\% centrate). At the other centrate concentrations, both at high and low light, depuration results were mostly less than $36 \%$. Unexpectedly, the highest phosphorus removal rate was almost the same at 200 and $1000 \mu \mathrm{E} /$ $\mathrm{m}^{2} \mathrm{~s}$ at 0.15 and $0.14 \mathrm{~g} / \mathrm{m}^{2}$ day, respectively - at the lower light intensity, this increased as the centrate concentration increased (Fig. 6B).

\subsubsection{Optimization of culture depth}

To further evaluate the potential of the native strain for cultivation in an open raceway, another critical criterion that should be considered, culture depth, was investigated in semi-continuous mode at 0.30 day $^{-1}$.

Fig. $4 \mathrm{C}$ presents the variation in biomass productivity as a function of the culture depth tested. The maximum biomass productivity $\left(22.20 \mathrm{~g} / \mathrm{m}^{2}\right.$ day) was attained at $15 \mathrm{~cm}$.

The photosynthetic activity measurements of the various cultures (Fig. 4D) were constant and similar for the different experiments, indicating that no growth inhibition occurred despite the high centrate percentage $(60 \%)$ used.

The effect of culture depth on the biochemical composition of 
the harvested biomass at steady state was determined and the results are reported in Fig. 5D. Regarding the protein content, one can observe that the highest amount $(26.40 \% \mathrm{~d} w \mathrm{wt})$ was obtained at a $10 \mathrm{~cm}$ culture depth while the carbohydrate contents decreased as the culture depth increased - down to $30.30 \% \mathrm{~d}$ wt at a $20 \mathrm{~cm}$ culture depth. As regards the lipid content, this increased as the culture depth increased (except for a slight decrease observed at $15 \mathrm{~cm}$ )- the maximum amount reached was $19.30 \% \mathrm{~d} w \mathrm{w}$. The fatty acid content and profile were examined and the data are presented in Table 4. The profile showed the dominance of C16:0, C16:2n4 and C18:1n9. The algal methyl esters were mainly saturated and monounsaturated fatty acids constituting more than $50 \%$ of the total fatty acids for the different culture depths studied -as this parameter increased, the total fatty acids increased - reaching $60.40 \%$ at $15 \mathrm{~cm}$, the best culture depth for biomass productivity.

As far as the nitrogen and phosphorus removal was concerned, analyses of these nutrients inlet and outlet concentrations at steady state were performed. The variation in ammonium depuration as a function of culture depth is illustrated in Fig. S4A in supplementary materials. The results show that ammonium elimination decreased as the culture depth increased; the highest value obtained was at $5 \mathrm{~cm}(97.60 \%)$.

Regarding phosphorus, the results are provided in Fig. S4B in supplementary materials. Phosphorus elimination was not correlated to ammonium elimination; to the contrary, it increased as the culture depth increased, and the highest depuration (80\%) was obtained at the $15 \mathrm{~cm}$ culture depth (Fig. S4B, supplementary materials). The phosphorus removal rates ranged from 0.10 to $0.40 \mathrm{gP} /$ $\mathrm{m}^{2}$ day, increasing as the culture depth increased (Fig. 6D).

\section{Discussion}

To determine the appropriate dilution rate to be used for ensuring both the highest microalgae productivity and efficient nutrient removal, as well as to study the tolerance of the Scenedesmus sp. strain to the centrate concentration, different combinations of these two parameters -the dilution rate $(0.04-0.401 /$ day) and the centrate percentage (15-60\%) were applied. The experiments were performed in newly designed open reactors simulating the cultivation conditions in raceways, at a maximal impinging irradiance of $200 \mu \mathrm{E} \mathrm{m}^{-2} \mathrm{~s}^{-1}$ during the circadian cycle and with $5 \mathrm{~cm}$ of culture depth.

The mixing time for these reactors was $13 \mathrm{~s}$, which showed vertical mixing similar to that previously determined for raceway reactors (Mendoza et al., 2013a). Moreover, this mixing time is much lower than characteristics time of growth (days) or dilution (h), thus ensuring perfect mixing conditions from the biomass and culture medium composition point of view. Regarding the mass transfer coefficient, the value determined for the racewaysimulating reactor was $4.72 \mathrm{~h}^{-1}$, which is in the value range reported for a real-scale open raceway reactor (Mendoza et al., 2013b). This value can limit the oxygen desorption if high oxygen production rates, and consequently high biomass productivities, were achieved into the culture system. Thus, the dissolved oxygen concentration can increase up to $13 \mathrm{mg} / \mathrm{L}$ (163 \%Sat.) at biomass productivities up to $0.1 \mathrm{~g} / \mathrm{L} \cdot$ day, and up to $18 \mathrm{mg} / \mathrm{L}$ (225\%Sat.) at biomass productivities up to $0.2 \mathrm{~g} / \mathrm{L} \cdot$ day. Because the highest biomass productivity measured at $5 \mathrm{~cm}$ culture depth and $200 \mu \mathrm{E} /$ $\mathrm{m}^{2} \mathrm{~s}$, was $0.16 \mathrm{~g} / \mathrm{L}$. day the maximum dissolved oxygen concentration achievable was $16 \mathrm{mg} / \mathrm{L}$ (200\%Sat.), thus confirming the potential existence of problems related to dissolved oxygen accumulation excess.

\subsection{Effect of dilution rate and centrate percentage}

Productivities ranging from 2.10 to $7.80 \mathrm{~g} / \mathrm{m}^{2}$ day were obtained (Fig. 1). These productivities are lower than those found in some studies, but they are within the range of values reported elsewhere (Table 5) The highest biomass productivity here recorded (7.80 g/ $\mathrm{m}^{2}$ day) at $200 \mu \mathrm{E} / \mathrm{m}^{2} \mathrm{~s}$ and $5 \mathrm{~cm}$ culture depth is higher than reported in previous works (Table 5).

On one hand, this type of reactor suffers from certain limitations such as high dissolved oxygen accumulation (Acién Fernández et al., 2013). Since there was no air bubbling to remove the dissolved oxygen produced in this reactor system, there may have been an inhibitory effect on photosynthesis (Mendoza et al., 2013b; Molina et al., 2001) and consequently on productivity.

On the other hand, these low productivities could also be largely attributed to the low light impinging intensity $\left(200 \mu \mathrm{E} / \mathrm{m}^{2} \mathrm{~s}\right)$ utilized in the experiments rather than to an inhibiting effect due to using centrate as the culture medium; given that the results showed biomass productivity increasing along with an increase in centrate percentage in the medium, or in relation to the dilution rate imposed.

No growth inhibition was observed at high centrate percentage as demonstrated from chlorophyll fluorescence results (Fig. 1C). For instance, Osundeko and Pittman (2014) observed a detrimental effect at $40 \%$ centrate on the growth of Parachlorella hussii and Chlorella letuoviridis strains at lab scale in semi-continuous mode, whilst growth inhibition was recorded for the other strains studied. Similarly, Morales-Amaral et al. (2015b), who cultivated Pseudokirchneriella subcapitata and Muriellopsis sp. in semi-continuous mode at 0.31 /day, reported that chlorophyll fluorescence of $P$. subcapitata went down from 0.6 to 0.49 when using $60 \%$ centrate.

The biochemical composition of the produced biomass was characterized (Fig. 2). The sugar content under the tested conditions was higher than the $21.9-42.6 \%$ reported by Batista et al. (2015), and comparable to that found by Jebali et al. (2015). The protein amounts obtained in this study were lower than those found in other works (Sepúlveda et al., 2015) and comparable to those obtained by Gómez et al. (2013) using domestic wastewater. Regarding lipid content, it is interesting to note that: (1) the highest lipid content was achieved at the lowest dilution rate tested $(0.041 /$ day); and (2) that no lipid content enhancement was observed as the centrate concentration increased (Fig. 2C), indicating that the medium used was not sufficiently stressful to trigger lipid accumulation, as demonstrated in many studies conducted on cultures under stress conditions (Xin et al., 2010). Comparable lipid contents were obtained by Batista et al. (2015) and Arbib et al. (2014) but higher amounts were determined in other previous studies. For example, a lipid content in the $20-42 \%$ range was reported from the cultivation of $C$. vulgaris in a semi-continuously-operated column aeration photobioreactor using artificial wastewater (Feng et al., 2011); while Ji et al. (2013) reported a lipid range of $22-32 \%$ cultivating different strains in batch mode using tertiarytreated municipal wastewater, with or without $\mathrm{CO}_{2}$; and Sydney et al. (2011) obtained a lipid amount of 36.14\% from Botryoccocus braunii LEM 14 produced in secondary-treated effluent after 14 days batch mode cultivation. However, as claimed by the authors, these results were relevant because cultures were grown under nutrient-deprived conditions. It is important to note that while lipid accumulation drastically increases under nutrient-limited conditions, biomass productivity increases under nutrientsufficient conditions. Several studies have concluded that biomass productivity should be the focus of microalgae cultivation, rather than lipid content, to achieve viable biofuel production (Pittman et al., 2011; Sutherland et al., 2015).

Analyses of fatty acids were performed (Table 2). Similarly, these 

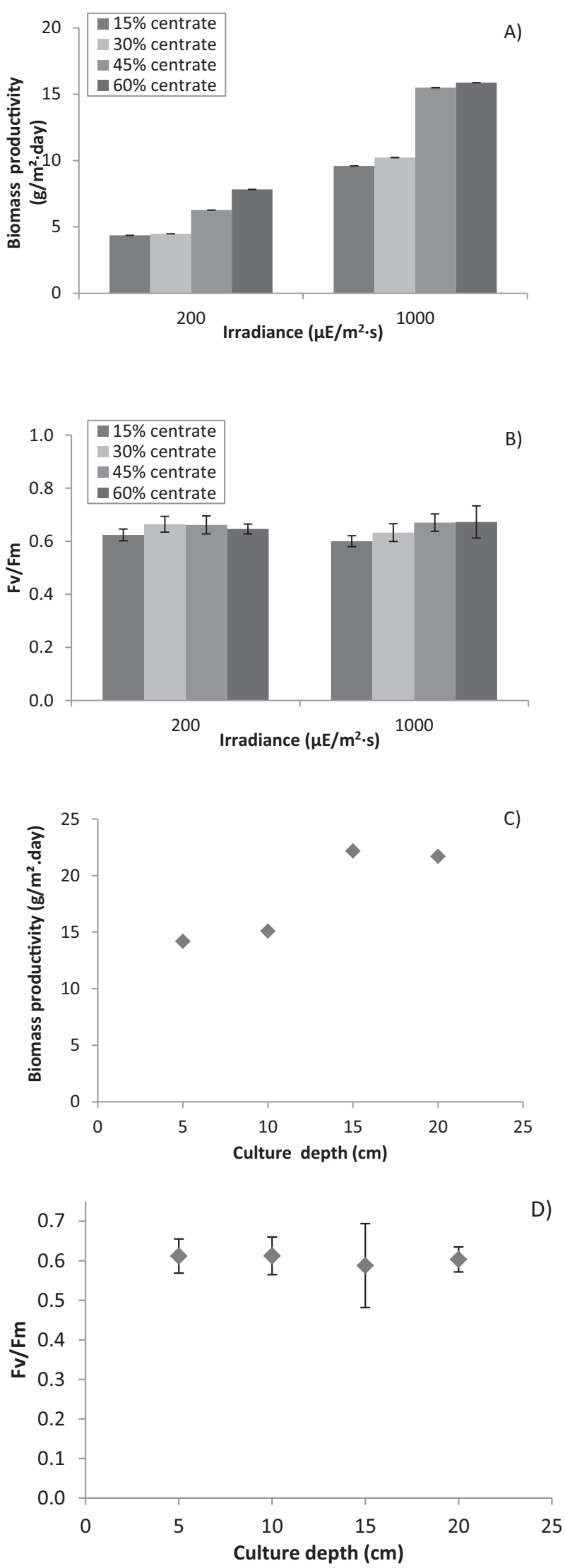

Fig. 4. Semi-continuously-fed culture of Scenedesmus sp. at $0.301 /$ day. Effect of light intensity using different centrate concentrations (A and B) and effect of culture depth (C and D) on nitrogen and phosphorus removal rates, respectively. Maximum impinging irradiances, 200 and $1000 \mu \mathrm{E} \mathrm{m}^{-2} \mathrm{~s}^{-1}$.

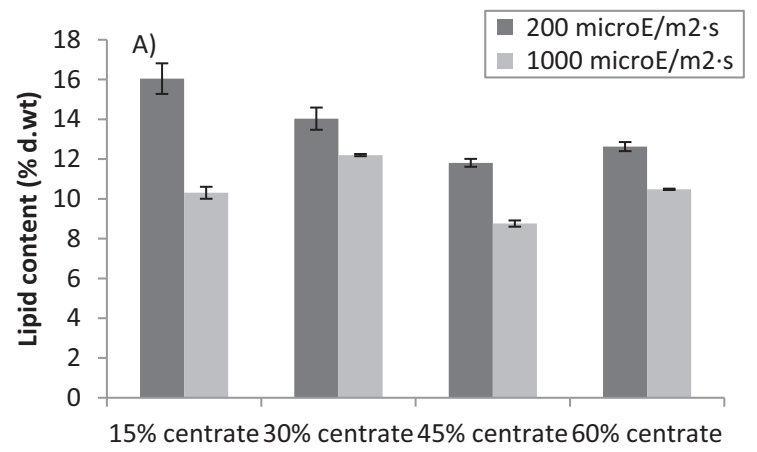

B)

$200 \mathrm{microE} / \mathrm{m} 2 \cdot \mathrm{s}$
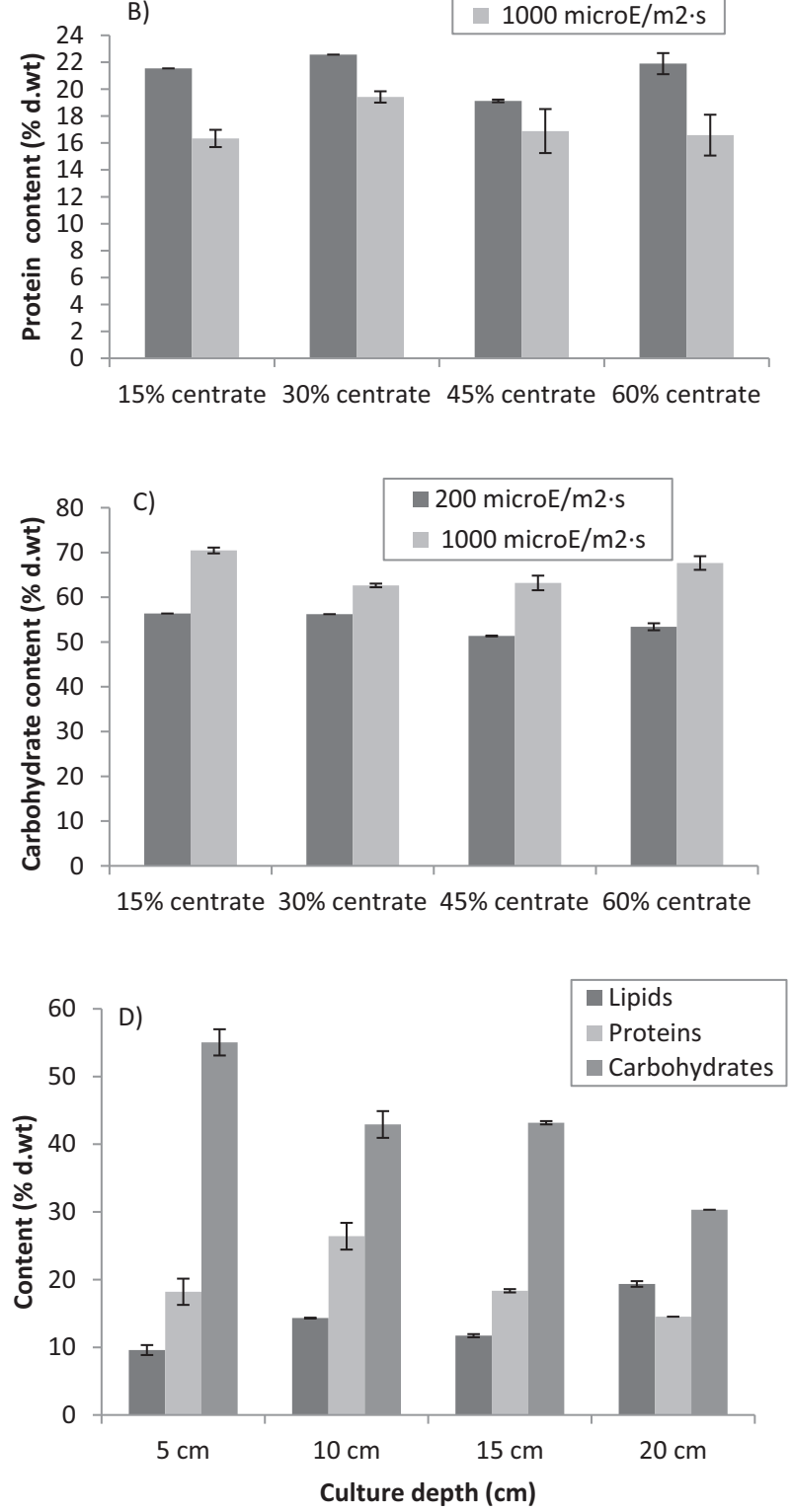

Fig. 5. Variations in the biochemical composition (A) Lipid content, (B) Protein content and $(C)$ carbohydrate content (Maximum impinging irradiances, 200 and $1000 \mu \mathrm{E}$ $\mathrm{m}^{-2} \mathrm{~s}^{-1}$ ) as a function of light intensity using different centrate concentrations and of culture depth (C) (Maximum impinging irradiance, $1000 \mu \mathrm{E} \mathrm{m}^{-2} \mathrm{~s}^{-1}$ ). Culture of Scenedesmus sp. was in semi-continuous mode at $0.301 /$ day. 
Table 3

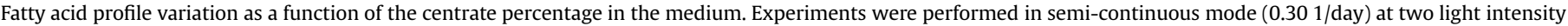
levels (200 and $\left.1000 \mu \mathrm{E} / \mathrm{m}^{2} \mathrm{~s}\right)$. Data values are means $( \pm \mathrm{SE})$ of duplicate samples.

\begin{tabular}{|c|c|c|c|c|c|c|c|c|}
\hline \multirow[t]{2}{*}{ F.A. } & \multicolumn{4}{|l|}{$200 \mu \mathrm{E} / \mathrm{m}^{2} \mathrm{~s}$} & \multicolumn{4}{|c|}{$1000 \mu \mathrm{E} / \mathrm{m}^{2} \mathrm{~s}$} \\
\hline & $15 \%$ & $30 \%$ & $45 \%$ & $60 \%$ & $15 \%$ & $30 \%$ & $45 \%$ & $60 \%$ \\
\hline $16: 0$ & 20.50 & 18.70 & 17.30 & 19.00 & 23.30 & 19.70 & 21.30 & 22.90 \\
\hline $16: 1 \mathrm{n} 7$ & 4.00 & 5.90 & 4.60 & 5.50 & - & - & - & - \\
\hline $16: 2 \mathrm{n} 4$ & 10.60 & 13.90 & 12.30 & 11.40 & 15.50 & 15.60 & 9.20 & 9.60 \\
\hline $16: 3 n 4$ & 10.60 & 7.70 & 8.10 & 9.00 & 10.90 & 8.60 & 18.90 & 19.40 \\
\hline $16: 4 n 1$ & - & - & - & - & - & - & - & - \\
\hline $18: 0$ & 9.30 & 7.90 & 9.20 & 9.30 & 11.20 & 11.80 & 11.90 & 10.60 \\
\hline $18: 1 \mathrm{n} 9$ & 20.60 & 22.40 & 24.50 & 23.80 & 17.90 & 18.90 & 18.90 & 18.30 \\
\hline $18: 1 \mathrm{n} 7$ & - & - & - & - & - & - & - & - \\
\hline $18: 2 \mathrm{n} 6$ & - & - & - & - & - & - & - & - \\
\hline $18: 3 n 3$ & 4.20 & 2.90 & 2.60 & 3.30 & 5.90 & 3.60 & 3.90 & 3.70 \\
\hline $\mathrm{FA}, \% \mathrm{~d} w \mathrm{t}$ & $4.40 \pm 0.00$ & $3.10 \pm 0.09$ & $3.30 \pm 0.00$ & $3.60 \pm 0.13$ & $3.10 \pm 0.08$ & $2.90 \pm 0.02$ & $4.90 \pm 0.31$ & $4.40 \pm 0.07$ \\
\hline
\end{tabular}

fatty acid classes have been determined in previous studies, at different amounts depending on the various wastewater compositions as well as the culture conditions (Jebali et al., 2015; Ji et al., 2013; Sydney et al., 2011). At the dilution rate (0.30 1/day) and centrate percentage $(60 \%)$ ensuring optimal biomass productivity, the lipid content was $12.60 \%$ whilst the saturated and monosaturated fatty acid content accounted for $57.70 \%$ of total fatty acids.

The mechanisms for macro and micro-contaminant elimination in microalgae-based wastewater systems are mainly physiochemical/abiotic processes such as sorption, photodegradation, precipitation and volatilization and biotic processes including algal up-take and biodegradation (Matamoros et al., 2015; Min et al., 2014; Tan et al., 2015). The data of ammonium removal efficiency obtained are in the range of those reported in the literature (Morales-Amaral et al., 2015a, b; Zhou et al., 2012a, 2012b) and higher than those recounted in some other studies (Table 5). For instance, at $0.301 /$ day and at an irradiance of $200 \mu \mathrm{E} / \mathrm{m}^{2} \mathrm{~s}$, the nitrogen removal efficiencies here reported were $68 \%$ and $51 \%$ for 151.10 and for $217.50 \mathrm{mg} / \mathrm{L}$ initial ammonium concentration, respectively (Fig. S1 A). This was higher than the values of around $25 \%$ and $40 \%$ at 300 and $500 \mu \mathrm{E} / \mathrm{m}^{2}$ s, respectively, determined by Sepúlveda et al. (2015), who investigated the cultivation of $N$. gaditana at 0.251 /day with an initial ammonium concentration of $191.5 \mathrm{mg} / \mathrm{L}$. Regarding nitrogen removal rates (Fig. 3A), the values determined here are comparable to those previously reported in the literature (Table 5).

According to many studies, the phosphorus-removing mechanisms are either assimilation by microalgae or precipitation due to high pH (Ruiz-Martinez et al., 2012; Zhou et al., 2012b). Low phosphorus removal rates were determined (Fig. 3B). During this study, the $\mathrm{pH}$ was controlled at 8.00 -thus, chemical precipitation was unlikely and the phosphorus removal was presumed to be due to microalgal metabolic assimilation. Therefore, this low removal rate might indicate that phosphorus was provided in excess with respect to the nitrogen supply. Comparative low phosphorus elimination values and similar behavior was observed in previous studies. Morales-Amaral et al. (2015a) who conducted outdoor raceway cultivation of Scenedesmus. sp using centrate as the culture medium (10\% phosphorus removal efficiency) and Posadas et al. (2014), who investigated nutrient removal from domestic water using an open algal-bacterial biofilm pond ( 49 and $27 \%$ phosphorus removal efficiencies were determined at hydraulic retention times of 7 and 5 days, equivalent to 0.141 /day and 0.201 /day of dilution rates, respectively).

The highest phosphorus removal rates reported here at 30 and $60 \%$ centrate at $0.401 /$ day are similar to those previously determined (Table 5).

\subsection{Light and culture depth effects}

To investigate the effect of light and culture depth on biomass productivity and nutrient removal efficiency, four experiments were conducted using four different centrate and tap water mixtures $(15,30,45$ and $60 \%)$ in semi-continuous mode at the dilution rate previously selected 0.301 /day in four lab-scale open racewaysimulating reactors, testing two different light intensity levels of a maximum 200 and $1000 \mu \mathrm{E} / \mathrm{m}^{2} \mathrm{~s}$. The culture depth experiments were carried out at 5, 10, 15 and $20 \mathrm{~cm}$ under the previously optimized conditions: dilution rate $0.301 /$ day, $60 \%$ centrate and $1000 \mu \mathrm{E} / \mathrm{m}^{2} \mathrm{~s}$.

\subsubsection{Impact of light}

The biomass productivity reported here at high light intensity of $1000 \mu \mathrm{E} / \mathrm{m}^{2} \mathrm{~s}\left(15.90 \mathrm{~g} / \mathrm{m}^{2}\right.$ day $)$ was higher than those determined in several other studies (Table 5) (Fig. 4A). On the other hand, the productivity achieved in this study fell within the range of productivities reported when using wastewater in raceways elsewhere (Table 5).

Additionally, the native Scenedesmus sp. strain expressed higher biomass productivity for all the centrate concentrations tested when the light intensity increased from 200 to $1000 \mu \mathrm{E} / \mathrm{m}^{2} \mathrm{~s}$. In fact, the photosynthesis rate is a function of the irradiance applied to the culture, linearly increasing with irradiance until saturating the photosynthetic reaction centers (Formighieri et al., 2012).

According to fluorescence chlorophyll results, no stress was observed because of high centrate percentage used (Fig. 4B). The growth inhibiting concentration of ammonium is species dependent. For instance, Muriellopsis sp. was capable of growing in an ammonium concentration up to $160 \mathrm{mg} / \mathrm{L}$ whereas $P$. subcapitata had reduced capability at ammonium inlet concentrations above $100 \mathrm{mg} / \mathrm{L}$ (Morales-Amaral et al., 2015b). In another study, Ji et al. (2014) claimed that Desmodesmus sp. EJ9-6 was inhibited by an ammonia concentration of $100 \mathrm{mg} / \mathrm{L}$. Therefore, selecting the appropriate ammonium-tolerant strain is a crucial step in improving the stability of the microalgal-based centrate remediation process.

The biochemical composition of the produced biomass showed that lipid content increased as light intensity decreased (Fig. 5). This behavior is expected for microalgae culture where the biomass composition is known to be greatly dependent on light supply, temperature and medium composition (Molina-Grima et al., 1999; Tzovenis et al., 2003). Thus, when the growth rate was high, as in experiments at $0.301 /$ day (Fig. 1C) and at $1000 \mu \mathrm{E} \mathrm{m}^{-2} \mathrm{~s}^{-1}$ (Fig. 4A), the total lipid content was low while the percentage of structural lipids in biomass (mainly composed of polyunsaturated fatty acids) with respect to neutral lipids was high. This may explain the 

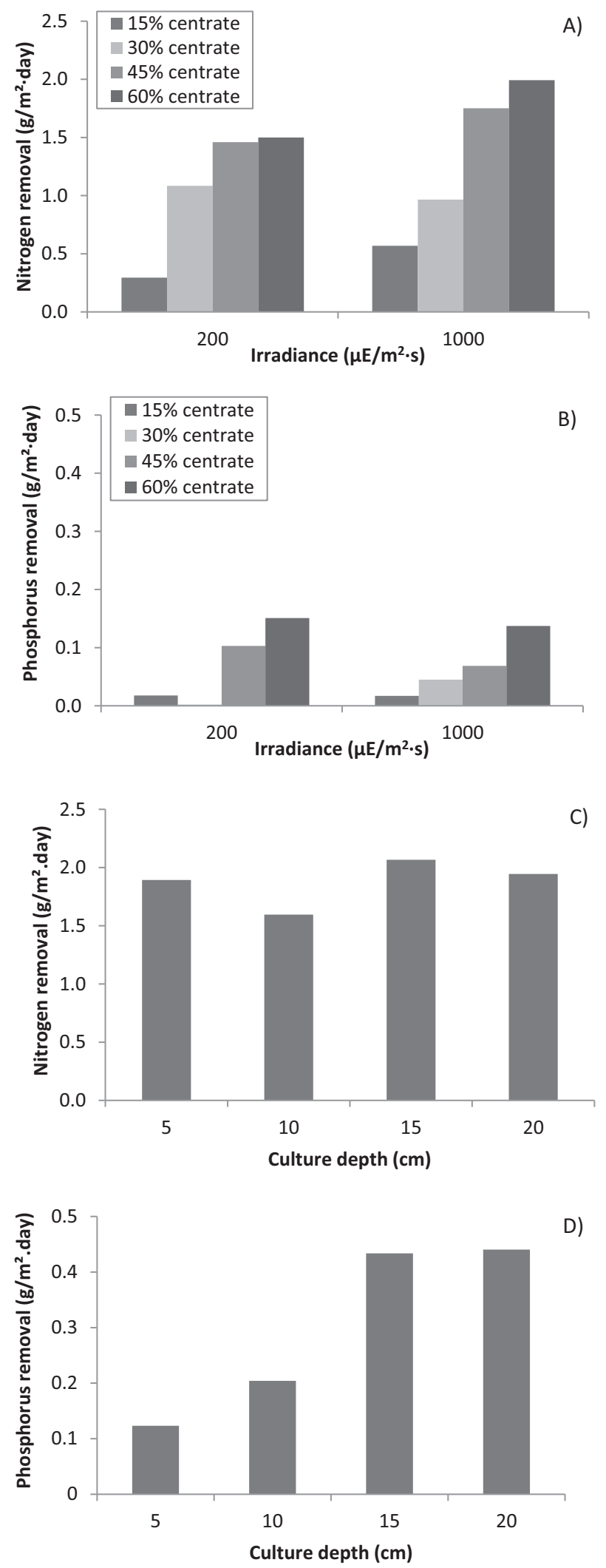

Fig. 6. Semi-continuously-fed culture of Scenedesmus sp. at 0.301 /day. Effect of light intensity and centrate concentration on biomass productivity (A) and $\mathrm{Fv} / \mathrm{Fm}$ (B) (Maximum impinging irradiances, 200 and $1000 \mu \mathrm{E} \mathrm{m}^{-2} \mathrm{~s}^{-1}$ ). Effect of culture depth on biomass productivity (C) and $\mathrm{Fv} / \mathrm{Fm}$ (D) (Maximum impinging irradiance, $1000 \mu \mathrm{E}$ $\mathrm{m}^{-2} \mathrm{~s}^{-1}$ ). Data values are means $( \pm \mathrm{SE})$ of duplicate samples.
Table 4

Fatty-acid profile variation as a function of culture depth. Experiments were performed in semi-continuous mode (0.30 1/day) in 60\% centrate. Data values are means $( \pm$ SE) of duplicate samples.

\begin{tabular}{lllll}
\hline F.A. & $5 \mathrm{~cm}$ & $10 \mathrm{~cm}$ & $15 \mathrm{~cm}$ & $20 \mathrm{~cm}$ \\
\hline $16: 0$ & 19.70 & 18.70 & 18.40 & 18.00 \\
$16: 1 \mathrm{n} 7$ & 2.90 & 4.90 & 6.20 & 4.10 \\
$16: 2 \mathrm{n} 4$ & 14.40 & 21.30 & 14.80 & 14.30 \\
$16: 3 \mathrm{n} 4$ & 11.00 & 7.50 & 7.20 & 8.50 \\
$16: 4 \mathrm{n} 1$ & - & - & - & - \\
$18: 0$ & 11.40 & 7.00 & 9.20 & 9.20 \\
$18: 1 \mathrm{n} 9$ & 23.10 & 22.90 & 26.50 & 34.00 \\
$18: 1 \mathrm{n} 7$ & - & - & - & - \\
$18: 2 \mathrm{n} 6$ & - & - & - & - \\
$18: 3 \mathrm{n} 3$ & 3.80 & 2.50 & 2.40 & 2.90 \\
FA, \%d wt & $2.90 \pm 0.15$ & $2.20 \pm 0.03$ & $2.90 \pm 0.17$ & $3.00 \pm 0.14$ \\
\hline
\end{tabular}

increase in the content of polyunsaturated fatty acids (16:3n4 and 18:3n3) (Tables 2 and 3 ) in these experiments. In contrast, under stressful conditions, as the production of all cell components and the cell growth are greatly retarded, the production of energy-rich lipids remains high resulting in their accumulation. (Molina-Grima et al., 1999; Lam and Lee, 2012). Lipid content range determined in this study fell within th values previously reported in the literature for wastewater-grown microalgae (Chinnasamy et al., 2010; Pittman et al., 2011).

Regarding nutrients removal, the higher was the light intensity, higher is the nitrogen removal (Fig. 6A). In fact, Lee and Lee (2001) stated that ATP and NADPH, both nitrogen containing compounds, are actively synthesized when microalgae undergo photosynthesis or when the cells are illuminated.

The optimal nitrogen removal rate $\left(2 \mathrm{~g} / \mathrm{m}^{2}\right.$ day) was higher or comparable to previously reported values in the literature (Table 5).

Regarding phosphorus, low removal efficiency was observed. Likewise, low phosphorus depuration of less than $30 \%$ was observed at an initial $\mathrm{P}_{-} \mathrm{PO}_{4}^{3-}$ concentration higher than $7.70 \mathrm{mg} / \mathrm{L}$ (Aslan and Kapdan, 2006) whereas the uptake capability of C. kessleri was only $8-20 \%$ under the light/dark cycle for a $\mathrm{P}_{-} \mathrm{PO}_{4}^{3-}$ concentration of $10 \mathrm{mg} / \mathrm{L}$ (Lee and Lee, 2001).

Phosphorus removal rates were ranging from 0.02 to $0.15 \mathrm{~g} /$ $\mathrm{m}^{2}$ day (Fig. 6B). A similar range of phosphorus removal rates values is reported in the literature (Table 5).

Considering these results, one can conclude that for the native strain Scenedesmus sp., biomass productivity as well as nutrient uptake and removal rates were enhanced under the optimized conditions of high light intensity $\left(1000 \mu \mathrm{E} / \mathrm{m}^{2} \mathrm{~s}\right)$ and $60 \%$ centrate dilution. A biomass productivity of $15.90 \mathrm{~g} / \mathrm{m}^{2}$ day was obtainable, along with a nitrogen and phosphorus removal capacity of $2.00 \mathrm{~g} /$ $\mathrm{m}^{2}$ day and $0.14 \mathrm{~g} / \mathrm{m}^{2}$ day, respectively. The native strain showed good tolerance to high ammonium concentrations up to $230.00 \mathrm{mg} / \mathrm{L}$ and it could be efficiently cultivated in semicontinuous mode for sustainable and stable biomass production and for a nutrient removal system using centrate as the culture medium. According to the International Energy Agency review (2011), high levels of sustained biomass productivity in open ponds fall within the $15-40 \mathrm{~g} \mathrm{~m}^{-2} \mathrm{~d}^{-1}$ range.

\subsubsection{Impact of culture depth}

The maximum productivity reported here at $15 \mathrm{~cm}$ culture depth, $1000 \mu \mathrm{E} / \mathrm{m}^{2} \mathrm{~s}, 0.301 /$ day and $60 \%$ centrate $\left(22.20 \mathrm{~g} / \mathrm{m}^{2}\right.$ day $)$ is comparable to that obtained in the literature and higher than the maximum productivity reported in other studies (Fig. 4C) (Table 5).

Regarding biomass biochemical composition, lipid content was higher, the higher was the culture depth (Fig. 5D). This trend might be explained by the fact that at a greater depth, such as $20 \mathrm{~cm}$, the 
Table 5

Comparison of productivity, nitrogen and phosphorus removal rates in microalgae-based treatment system of wastewater.

\begin{tabular}{|c|c|c|c|c|c|c|}
\hline Microalgae strain & Reactor type & Wastewater & Conditions & Productivity & $\begin{array}{l}\mathrm{N} \text { and } \mathrm{P} \text { removal } \\
\text { rate }\end{array}$ & Reference \\
\hline Scenedesmus sp. & $\begin{array}{l}\text { Raceway simulating } \\
\text { reactor }\end{array}$ & $60 \%$ Centrate & $\begin{array}{l}200 \mu \mathrm{mol} \mathrm{m}^{-2} \mathrm{~s}^{-1} \\
5 \mathrm{~cm} \text { culture depth }\end{array}$ & $7.80 \mathrm{~g} / \mathrm{m}^{2} \mathrm{~d}$ & $\begin{array}{l}\mathrm{N}: 30 \mathrm{mg} / \mathrm{Ld} \\
\mathrm{P}: 3 \mathrm{mg} / \mathrm{Ld}\end{array}$ & This study \\
\hline Scenedesmus sp. & $\begin{array}{l}\text { Raceway simulating } \\
\text { reactor }\end{array}$ & $60 \%$ Centrate & $\begin{array}{l}1000 \mu \mathrm{mol} \mathrm{m}^{-2} \mathrm{~s}^{-1} \\
5 \mathrm{~cm} \text { culture depth }\end{array}$ & $15.90 \mathrm{~g} / \mathrm{m}^{2} \mathrm{~d}$ & $\begin{array}{l}\mathrm{N}: 39.86 \mathrm{mg} / \mathrm{Ld} \\
\mathrm{P}: 2.75 \mathrm{mg} / \mathrm{Ld}\end{array}$ & This study \\
\hline Scenedesmus sp. & $\begin{array}{l}\text { Raceway simulating } \\
\text { reactor }\end{array}$ & $60 \%$ Centrate & $\begin{array}{l}1000 \mu \mathrm{mol} \mathrm{m}^{-2} \mathrm{~s}^{-1} \\
15 \mathrm{~cm} \text { culture depth }\end{array}$ & $22.2 \mathrm{~g} / \mathrm{m}^{2} \mathrm{~d}$ & $\begin{array}{l}\mathrm{N}: 13.80 \mathrm{mg} / \mathrm{Ld} \\
\mathrm{P}: 2.90 \mathrm{mg} / \mathrm{Ld}\end{array}$ & This study \\
\hline Chlorella sp. & $\begin{array}{l}\text { Multi-layer } \\
\text { photobioreactor }\end{array}$ & $\begin{array}{l}20 \% \text { swine manure } \\
\text { wastewater }\end{array}$ & $\begin{array}{l}560.57 \\
-476.37 \mu \mathrm{mol} \mathrm{m}^{-2} \mathrm{~s}^{-1}\end{array}$ & $\begin{array}{l}\text { 14.59 TVSS } \mathrm{g} / \\
\mathrm{m}^{2} \mathrm{~d}\end{array}$ & $\begin{array}{l}\mathrm{NH}_{3}-\mathrm{N}: 2.65 \mathrm{~g} / \\
\mathrm{m}^{2} \mathrm{~d} \\
\text { TN: } 3.19 \mathrm{~g} / \mathrm{m}^{2} \mathrm{~d} \\
\text { P: } 0.067 \mathrm{~g} / \mathrm{m}^{2} \mathrm{~d}\end{array}$ & (Min et al., 2014) \\
\hline Nannochloropsis gaditana & Raceway pond & $30 \%$ of centrate & $\begin{array}{l}\text { Outdoor at } 0.2 \mathrm{~d}^{-1} \\
11 \mathrm{~cm} \text { culture depth }\end{array}$ & $0.1 \mathrm{~g} / \mathrm{L}$ day & $\begin{array}{l}\mathrm{N}: 14 \mathrm{mg} / \mathrm{Ld} \\
\mathrm{P}: 1.4 \mathrm{mg} / \mathrm{Ld}\end{array}$ & (Ledda et al., 2015) \\
\hline Chlorella sp. & $\begin{array}{l}\text { Pilot scale } \\
\text { photobioreactor }\end{array}$ & centrate & $\begin{array}{l}\text { semi-continuous mode; } \\
25 \mu \mathrm{mol} \mathrm{m}^{-2} \mathrm{~s}^{-1} \\
10.2 \mathrm{~cm} \text { culture depth }\end{array}$ & $\begin{array}{l}8.7-17.7 \text { VSS g/ } \\
\mathrm{m}^{2} \mathrm{~d}\end{array}$ & $\begin{array}{l}\mathrm{N}: 0.9-2.1 \mathrm{~g} / \\
\mathrm{m}^{2} \mathrm{~d} \\
\mathrm{P}: 2.7-6.9 \mathrm{~g} / \mathrm{m}^{2} \mathrm{~d}\end{array}$ & Min et al., 2011 \\
\hline Desmodesmus sp. EJ 9-6 & flask & $\begin{array}{l}10 \% \text { Anaerobic digestion } \\
\text { wastewater }\end{array}$ & $120 \mu \mathrm{mol} \mathrm{m}^{-2} \mathrm{~s}^{-1}$ & $0.029 \mathrm{~g} / \mathrm{Ld}$ & $\begin{array}{l}\mathrm{N}: 4.542 \mathrm{mg} / \mathrm{Ld} \\
\mathrm{P}: 0.29 \mathrm{mg} / \mathrm{Ld}\end{array}$ & Ji et al., 2014 \\
\hline Scenedesmus sp. & Pilot scale raceway & centrate & $\begin{array}{l}\text { Outdoor at } 0.3 \mathrm{~d}^{-1} \\
11 \mathrm{~cm} \text { culture depth }\end{array}$ & $\begin{array}{l}0.2 \mathrm{~g} / \mathrm{L} \text { day or } \\
24 \mathrm{~g} / \mathrm{m}^{2} \text { day }\end{array}$ & $\begin{array}{l}\mathrm{N}: 38 \mathrm{mg} / \mathrm{Ld} \\
\mathrm{P}: 3.9 \mathrm{mg} / \mathrm{Ld}\end{array}$ & $\begin{array}{l}\text { Morales-Amaral, } \\
\text { 2015a }\end{array}$ \\
\hline C. pyrenoidosa & $\begin{array}{l}\text { Rectangular } \\
\text { photobioreactor }\end{array}$ & $\begin{array}{l}\text { Diluted anaerobically } \\
\text {-digested activated } \\
\text { sludge }\end{array}$ & $\begin{array}{l}42.58-98.67 \\
\mu \mathrm{mol} \mathrm{m}^{-2} \mathrm{~s}^{-1}\end{array}$ & $0.291 \mathrm{~g} / \mathrm{m}^{3} \mathrm{~d}$ & $\begin{array}{l}\mathrm{N}: 36.8 \mathrm{mg} / \mathrm{Ld} \\
\mathrm{P}: 6.1 \mathrm{mg} / \mathrm{Ld}\end{array}$ & Tan et al., 2015 \\
\hline P. subcapitata & Bubble columns & centrate & $800 \mu \mathrm{mol} \mathrm{m}{ }^{-2} \mathrm{~s}^{-1}$ & $1.02 \mathrm{~g} / \mathrm{Ld}$ & $\begin{array}{l}\mathrm{N}: 27 \mathrm{mg} / \mathrm{Ld} \\
\mathrm{P}: 2.7 \mathrm{mg} / \mathrm{Ld}\end{array}$ & $\begin{array}{l}\text { Morales-Amaral, } \\
\text { 2015b }\end{array}$ \\
\hline Chlorella vulgaris & flask & Synthetic wastewater & $55.34 \mu \mathrm{mol} \mathrm{m}^{-2} \mathrm{~s}^{-1}$ & - & $\begin{array}{l}\mathrm{N}: 10.5 \mathrm{mg} / \mathrm{Ld} \\
\mathrm{P}: 2 \mathrm{mg} / \mathrm{Ld}\end{array}$ & $\begin{array}{l}\text { Aslan and Kapdan, } \\
2006\end{array}$ \\
\hline Algal consortium & raceway & carpet industrial effluent & $\begin{array}{l}\text { batch mode at } 18 \mathrm{~cm} \\
\text { batch mode at } 20 \mathrm{~cm} \\
\text { batch mode at } 30 \mathrm{~cm}\end{array}$ & $\begin{array}{l}10.36 \mathrm{~g} / \mathrm{m}^{2} \text { day } \\
7.79 \mathrm{~g} / \mathrm{m}^{2} \text { day } \\
6.43 \mathrm{~g} / \mathrm{m}^{2} \text { day }\end{array}$ & - & $\begin{array}{l}\text { Chinnasamy et al. } \\
\text { (2010) }\end{array}$ \\
\hline Algal consortium & Pilot scale raceway & $\begin{array}{l}\text { anaerobically } \\
\text { digested liquid } \\
\text { manure effluent }\end{array}$ & $\begin{array}{l}\text { Outdoor; semi-continuous } \\
\text { mode }\end{array}$ & $6.83 \mathrm{~g} / \mathrm{m}^{2}$ day & - & Chen et al. (2012) \\
\hline Chlorella vulgaris & flasks & $\begin{array}{l}\text { Primary domestic } \\
\text { effluent }+25 \mathrm{mM} \text { glycerol }\end{array}$ & $174 \mu \mathrm{mol} \mathrm{m}^{-2} \mathrm{~s}^{-1}$ & $0.107 \mathrm{~g} / \mathrm{L}$ day & $\begin{array}{l}\mathrm{N}: 3.52 \mathrm{mg} / \mathrm{Ld} \\
\mathrm{P}: 0.72 \mathrm{mg} / \mathrm{Ld}\end{array}$ & $\begin{array}{l}\text { Cabanelas et al., } \\
\text { 2013a }\end{array}$ \\
\hline Algal consortium & photobioreactor & $\begin{array}{l}\text { anaerobic membrane } \\
\text { bioreactor effluent }\end{array}$ & $\begin{array}{l}\operatorname{Max} 209 \mu \mathrm{mol} \mathrm{m}^{-2} \mathrm{~s}^{-1} 0.5 \\
\mathrm{~d}^{-1}\end{array}$ & $0.234 \mathrm{~g} / \mathrm{L}$ day & $\begin{array}{l}\mathrm{N}: 19.5 \mathrm{mg} / \mathrm{Ld} \\
\mathrm{P}: 3.7 \mathrm{mg} / \mathrm{Ld}\end{array}$ & $\begin{array}{l}\text { Ruiz-Martinez } \\
\text { et al. (2012) }\end{array}$ \\
\hline $\begin{array}{l}\text { Chlorella vulgaris SAG211- } \\
\quad 12\end{array}$ & Borosilicate bioreactor & centrate & $150 \mu \mathrm{mol} \mathrm{m}^{-2} \mathrm{~s}^{-1}$ & $0.195 \mathrm{~g} / \mathrm{L}$ day & $\begin{array}{l}\mathrm{N}: 9.80 \mathrm{mg} / \mathrm{Ld} \\
\mathrm{P}: 1.14 \mathrm{mg} / \mathrm{Ld}\end{array}$ & $\begin{array}{l}\text { Cabanelas et al., } \\
\text { 2013b }\end{array}$ \\
\hline $\begin{array}{l}\text { Auxenochlorella } \\
\quad \text { protothecoides UMN280 }\end{array}$ & 25 L BIOCOIL reactor & $\begin{array}{l}\text { Concentrated municipal } \\
\text { wastewater }\end{array}$ & $0.33 \mathrm{~d}^{-1}$ & $1.51 \mathrm{~g} / \mathrm{L}$ day & - & Zhou et al., 2012a \\
\hline Nannochloropsis gaditana & $\begin{array}{l}\text { bubble-column } \\
\text { photobioreactors }\end{array}$ & centrate & $\begin{array}{l}500 \mu \mathrm{mol} \mathrm{m}^{-2} \mathrm{~s}^{-1} \\
0.3 \mathrm{~d}^{-1}\end{array}$ & $0.4 \mathrm{~g} / \mathrm{L}$ day & $\begin{array}{l}\mathrm{N}: 35 \mathrm{mg} / \mathrm{Ld} \\
\mathrm{P}: 5.70 \mathrm{mg} / \mathrm{Ld}\end{array}$ & $\begin{array}{l}\text { Sepúlveda et al., } \\
2015\end{array}$ \\
\hline Scenedesmus sp. & Pilot scale raceway & $\begin{array}{l}\text { secondary domestic } \\
\text { wastewater }\end{array}$ & $\begin{array}{l}\text { Using flue gas } \\
\text { Using pure } \mathrm{CO} 2\end{array}$ & $\begin{array}{l}13 \mathrm{~g} / \mathrm{m}^{2} \mathrm{~d} \\
17 \mathrm{~g} / \mathrm{m}^{2} \mathrm{~d}\end{array}$ & $\begin{array}{l}\mathrm{N}: 41-29 \mathrm{mg} / \mathrm{g} \\
\text { TSS }{ }^{-1} \mathrm{~d}^{-1} \\
\text { P: } 5-3 \mathrm{mg} / \mathrm{g} \\
\text { TSS }^{-1} \mathrm{~d}^{-1}\end{array}$ & $\begin{array}{l}\text { Posadas et al. } \\
\text { (2015) }\end{array}$ \\
\hline
\end{tabular}

cultures are stressed by light limitation, which triggers lipid accumulation. Under optimal biomass productivity conditions, the lipid productivity was $17.30 \mathrm{mg} / \mathrm{L}$ day, which is within the range of values reported in the literature for wastewater-based cultures (Cabanelas et al., 2013b; Osundeko and Pittman, 2014). In the light of the fatty acid profile results determined from the different parameters tested (centrate concentration, dilution rate, light intensity and culture depth), a high monosaturated fatty acid content is observed. This would positively affect the properties of the fuel produced in terms of ignition quality, viscosity, combustion heat and oxidative stability (Rashid et al., 2008).

Consequently, the fatty acid profile of the native Scenedesmus sp. Microalgae strain is of great interest for use in biofuel production.

As for nutrients removal, the maximum nitrogen removal obtained was at $5 \mathrm{~cm}(97.60 \%)$. It should be noted that the highest nitrification was also observed at this culture depth (data not shown). However, it is worth noting that besides microalgae uptake, the ammonia stripping had probably contributed to ammonium removal. The expected contribution of this phenomena was low because of the low mass transfer coefficient previously determined $(4.721 / \mathrm{h})$, and the low driving force for ammonia desorption due to the controlled $\mathrm{pH}$ at 8.0, ammonia desorption being more relevant at $\mathrm{pH}$ upper than 9 .

Nitrogen removal rate ranged from 1.60 to $2.00 \mathrm{gN} / \mathrm{m}^{2}$ day (Fig. 6C) where the maximum $\left(2.00 \mathrm{gN} / \mathrm{m}^{2}\right.$ day or $13.80 \mathrm{mgN} / \mathrm{L}$ day $)$ was seen at the $15 \mathrm{~cm}$ culture depth; this is in accordance with the biomass productivity. The result is higher than previously reported (Table 5). Regarding phosphorus, the removal rate recorded at $15 \mathrm{~cm}$ was $0.40 \mathrm{~g} \mathrm{P} / \mathrm{m}^{2}$ day, which is higher than the values obtained by Cabanelas et al. (2013a) and Ji et al. (2014) (Fig. 6D) (Table 5).

In this study, key parameters (dilution rate, centrate concentration and culture depth) were investigated. However, it is important to note that these different input parameters are not all independent variables, but affect each other. Additionally, these parameters variation affects also the light availability in the cultures and the overall performance of the system and accordingly influences the biomass productivity and nutrients removal capacity.

Consequently, a $15 \mathrm{~cm}$ culture depth seemed to be the most 
appropriate depth to apply in a raceway pond using the native strain Scenedesmus sp. achieving a maximum biomass productivity of $22.20 \mathrm{~g} / \mathrm{m}^{2}$ day and nitrogen and phosphorus removal rates of $2.00 \mathrm{gN} / \mathrm{m}^{2}$ day and $0.40 \mathrm{gP} / \mathrm{m}^{2}$ day, respectively.

\section{Conclusion}

Despite the satisfactory performance of the strain, high outlet nutrient concentrations were determined in all the assays (except those at 0.041 /day using 15,45 and $60 \%$ centrate); these exceed the requirements of European Union Directive 98/15/CE for effluent disposal from urban wastewater treatment, which only permit $10 \mathrm{mg} / \mathrm{L}$ for total nitrogen and $1 \mathrm{mg} / \mathrm{L}$ for $\mathrm{P}_{-} \mathrm{PO}_{4}^{3-}$.Therefore, regarding the effluent outlet from microalgae treatment in the present study (with its current nutrient composition), this should be either recycled in the wastewater treatment plant or used as the culture medium for microalgae growth in a second stage cultivation under nutrient-limited conditions for lipid synthesis induction. Nevertheless, the optimization of these critical parameters (dilution rate, centrate concentration and culture depth) at lab scale allows determining the optimal cultivation conditions before considering scaling up. This would be a step forward from experimental concepts to practical realities for coupling wastewater treatment with microalgae biotechnology that showed potential for economic gains. In fact, besides removing nutrients from centrate, microalgal biomass could be useful for low value products application and consequently a source of revenues. For instance, bio-oil could be obtained from the whole microalgae biomass via hydrothermal liquefaction process and preferably from biomass presenting a lipid fraction composed of saturated and mono-saturated fatty acids (Biller and Ross, 2011; Yamaberi et al., 1998). Process residues could be valorized as feed/co-substrate for anaerobic digestion for bio-methane production. Such a clean combining activities approach would offset the costs of both wastewater treatment plant operations and microalgae biomass production. The native Scenedesmus sp. microalgae strain was cultivated in semi-continuously-fed open raceway-simulating reactors using different mixtures of tap water and centrate. The strain showed a high tolerance to elevated centrate concentrations where a biomass productivity of $7.80 \mathrm{~g} / \mathrm{m}^{2}$ day was obtained at $5 \mathrm{~cm}$ culture depth, $0.301 /$ day, $60 \%$ centrate and $200 \mu \mathrm{E} / \mathrm{m}^{2} \mathrm{~s}$. Under the same conditions, nitrogen and phosphorus removal rates of $1.50 \mathrm{~g} / \mathrm{m}^{2}$ day and $0.15 \mathrm{~g} / \mathrm{m}^{2}$ day were determined, respectively, along with a lipid content of $12.60 \%$.

After optimization of the irradiance and culture depth, a maximum biomass productivity of $22.20 \mathrm{~g} / \mathrm{m}^{2}$ day was achieved under optimal culture conditions of a $1000 \mu \mathrm{E} / \mathrm{m}^{2} \mathrm{~s}$ light intensity, $60 \%$ centrate, $0.301 /$ day and $15 \mathrm{~cm}$ culture depth. The maximum nitrogen and phosphorus removal rates were $2.00 \mathrm{gN} / \mathrm{m}^{2}$ day and $0.40 \mathrm{gP} / \mathrm{m}^{2}$ day, respectively. A lipid content of $11.70 \% \mathrm{dwt}$. was determined under optimal conditions along with a suitable fatty acid profile for biofuel production.

\section{Conflicts of interest}

None.

\section{Acknowledgements}

This study was supported by the Ministry of Higher Education and Scientific Research of Tunisia. Juan Antonio Membrillas and Juan Torres Castanada from Chemical Engineering Department, University of Almeria are gratefully acknowledged for their technical assistance. We also thank Aqualia S.A. for providing centrate samples.

\section{Appendix A. Supplementary data}

Supplementary data related to this article can be found at https://doi.org/10.1016/j.jenvman.2018.01.043.

\section{References}

Acién Fernández, F.G., Fernández Sevilla, J.M., Molina Grima, E., 2013. Photobioreactors for the production of microalgae. Rev. Environ. Sci. Biotechnol. 12, 131-151. https://doi.org/10.1007/s11157-012-9307-6.

Arbib, Z., Ruiz, J., Álvarez-Díaz, P., Garrido-Pérez, C., Perales, J.A., 2014. Capability of different microalgae species for phytoremediation processes: wastewater tertiary treatment, $\mathrm{CO} 2$ bio-fixation and low cost biofuels production. Water Res. 49, 465-474. https://doi.org/10.1016/j.watres.2013.10.036.

Aslan, S., Kapdan, I.K., 2006. Batch kinetics of nitrogen and phosphorus removal from synthetic wastewater by algae. Ecol. Eng. 28, 64-70. https://doi.org/ 10.1016/j.ecoleng.2006.04.003.

Avagyan, A.B., 2017. Environmental building policy by the use of microalgae and decreasing of risks for Canadian oil sand sector development. Environ. Sci. Pollut. Res. 24, 20241-20253. https://doi.org/10.1007/s11356-017-9864-X.

Avagyan, A.B., 2013. Theory of global sustainable development based on microalgae in bio and industrial cycles, management-changing decisions in areas of climate change and waste management. J. Sustain. Bioenergy Syst. 3, 287-297. https:// doi.org/10.4236/jsbs.2013.34038.

Avagyan, A.B., 2011. Water global recourse management through the use of microalgae addressed to sustainable development. Clean Technol. Environ. Pol. 13, 431-445. https://doi.org/10.1007/s10098-010-0321-5.

Avagyan, A.B., 2008. A contribution to global sustainable development: inclusion of microalgae and their biomass in production and bio cycles. Clean Technol. Environ. Pol. 10, 313-317. https://doi.org/10.1007/s10098-008-0180-5.

Batista, A.P., Ambrosano, L., Graça, S., Sousa, C., Marques, P.A.S.S., Ribeiro, B., Botrel, E.P., Castro Neto, P., Gouveia, L., 2015. Combining urban wastewater treatment with biohydrogen production - an integrated microalgae-based approach. Bioresour. Technol. 184, 230-235. https://doi.org/10.1016/ j.biortech.2014.10.064.

Benemann, J., 2013. Microalgae for biofuels and animal feeds. Energies 6, 5869-5886. https://doi.org/10.3390/en6115869.

Biller, P., Ross, A.B., 2011. Potential yields and properties of oil from the hydrothermal liquefaction of microalgae with different biochemical content. Bioresour. Technol. 102, 215-225. https://doi.org/10.1016/j.biortech.2010.06.028.

Borowitzka, M.A., Moheimani, N.R., 2010. Sustainable biofuels from algae. Mitig. Adapt. Strateg. Glob. Change 18, 13-25. https://doi.org/10.1007/s11027-0109271-9.

Cabanelas, I.T.D., Arbib, Z., Chinalia, F.A., Souza, C.O., Perales, J.A., Almeida, P.F., Druzian, J.I., Nascimento, I.A., 2013a. From waste to energy: microalgae production in wastewater and glycerol. Appl. Energy 109, 283-290. https://doi.org/ 10.1016/j.apenergy.2013.04.023.

Cabanelas, I.T.D., Ruiz, J., Arbib, Z., Chinalia, F.A., Garrido-Pérez, C., Rogalla, F., Nascimento, I.A., Perales, J.A., 2013b. Comparing the use of different domestic wastewaters for coupling microalgal production and nutrient removal. Bioresour. Technol. 131, 429-436. https://doi.org/10.1016/j.biortech.2012.12.152.

Chen, R., Li, R., Deitz, L., Liu, Y., Stevenson, R.J., Liao, W., 2012. Freshwater algal cultivation with animal waste for nutrient removal and biomass production. Biomass Bioenergy 39, 128-138. https://doi.org/10.1016/ j.biombioe.2011.12.045.

Chiaramonti, D., Prussi, M., Casini, D., Tredici, M.R., Rodolfi, L., Bassi, N., Zittelli, G.C., Bondioli, P., 2013. Review of energy balance in raceway ponds for microalgae cultivation: re-thinking a traditional system is possible. Appl. Energy 102, 101-111. https://doi.org/10.1016/j.apenergy.2012.07.040.

Chinnasamy, S., Bhatnagar, A., Claxton, R., Das, K.C., 2010. Biomass and bioenergy production potential of microalgae consortium in open and closed bioreactors using untreated carpet industry effluent as growth medium. Bioresour. Technol. 101, 6751-6760. https://doi.org/10.1016/j.biortech.2010.03.094.

Chisti, Y., 2012. Microalgal biotechnology: potential and production. In: Clemens, P., Walter, C. (Eds.), Microalgal Biotechnology: Potential and Production. DeGruyter, Göttingen, pp. 113-146.

Chisti, Y., 1999. Mass transfer. In: Flickinger, M., Drew, W. (Eds.), Encyclopedia of Bioprocess Technology Fermentation, Biocatalysis, and Biosepoaration. John wiley and Sons, INC, New York, USA, p. 1612.

Collos, Y., Harrison, P.J., 2014. Acclimation and toxicity of high ammonium concentrations to unicellular algae. Mar. Pollut. Bull. 80, 8-23. https://doi.org/ 10.1016/j.marpolbul.2014.01.006.

Davis, R., Markham, J., Kinchin, C., Grundl, N., Tan, E.C.D., Humbird, D., 2016. Process Design and Economics for the Production of Algal Biomass: Algal Biomass Production in Open Pond Systems and Processing through Dewatering for Downstream Conversion. https://doi.org/10.2172/1239893. Golden, CO (United States).

Dong, B., Ho, N., Ogden, K.L., Arnold, R.G., 2014. Cultivation of Nannochloropsis salina in municipal wastewater or digester centrate. Ecotoxicol. Environ. Saf. 103, 45-53. https://doi.org/10.1016/j.ecoenv.2014.02.001.

Feng, Y., Li, C., Zhang, D., 2011. Lipid production of Chlorella vulgaris cultured in artificial wastewater medium. Bioresour. Technol. 102, 101-105. https://doi.org/ 10.1016/j.biortech.2010.06.016. 
Formighieri, C., Franck, F., Bassi, R., 2012. Regulation of the pigment optical density of an algal cell: filling the gap between photosynthetic productivity in the laboratory and in mass culture. J. Biotechnol. 162, 115-123. https://doi.org/ 10.1016/j.jbiotec.2012.02.021.

Gómez, C., Escudero, R., Morales, M.M., Figueroa, F.L., Fernández-Sevilla, J.M., Acién, F.G., 2013. Use of secondary-treated wastewater for the production of Muriellopsis sp. Appl. Microbiol. Biotechnol. 97, 2239-2249. https://doi.org/ 10.1007/s00253-012-4634-7.

Herbert, D., Phipps, P.J., Strange, R.E., 1971. Methods in microbiology. In: Norris, J.R., Ribbons, D.W. (Eds.), Methods in Microbiology. Academic Press, London and New York, pp. 209-344.

Ichimura, T., Itoh, T., 1977. Preservation methods of microalgae (I). In: Nei, T. (Ed.), Preservation Methods of Microorganisms. University of Tokyo Press, Tokyo, pp. 355-373.

Jebali, A., Acién, F.G., Gómez, C., Fernández-Sevilla, J.M., Mhiri, N., Karray, F., Dhouib, A., Molina-Grima, E., Sayadi, S., 2015. Selection of native Tunisian microalgae for simultaneous wastewater treatment and biofuel production. Bioresour. Technol. 198, 424-430. https://doi.org/10.1016/ j.biortech.2015.09.037.

Ji, F., Liu, Y., Hao, R., Li, G., Zhou, Y., Dong, R., 2014. Biomass production and nutrients removal by a new microalgae strain Desmodesmus sp. in anaerobic digestion wastewater. Bioresour. Technol. 161, 200-207. https://doi.org/10.1016/ j.biortech.2014.03.034.

Ji, M.-K., Abou-Shanab, R.A.I., Kim, S.-H., Salama, E.-S., Lee, S.-H., Kabra, A.N., Lee, Y.S., Hong, S., Jeon, B.-H., 2013. Cultivation of microalgae species in tertiary municipal wastewater supplemented with $\mathrm{CO} 2$ for nutrient removal and biomass production. Ecol. Eng. 58, 142-148. https://doi.org/10.1016/ j.ecoleng.2013.06.020

Kochert, G., 1978. Handbook of Phycological Methods: Culture Methods and Growth Measurements, first. ed. Cambridge University Press, London.

Lam, M.K., Lee, K.T., 2012. Microalgae biofuels: a critical review of issues, problems and the way forward. Biotechnol. Adv. 30, 673-690. https://doi.org/10.1016/ j.biotechadv.2011.11.008

Lee, K., Lee, C.-G., 2001. Effect of light/dark cycles on wastewater treatments by microalgae. Biotechnol. Bioprocess. Eng. 6, 194-199. https://doi.org/10.1007/ BF02932550.

Ledda, C., Villegas, G.I.R., Adani, F., Fernández, F.G.A., Grima, E.M., 2015. Utilization of centrate from wastewater treatment for the outdoor production of Nannochloropsis gaditana biomass at pilot-scale. Algal 12, 17-25. https://doi.org/ 10.1016/j.algal.2015.08.002.

Matamoros, V., Gutiérrez, R., Ferrer, I., García, J., Bayona, J.M., 2015. Capability of microalgae-based wastewater treatment systems to remove emerging organic contaminants: a pilot-scale study. J. Hazard. Mater. 288, 34-42. https://doi.org/ 10.1016/j.jhazmat.2015.02.002.

Mendoza, J.L., Granados, M.R., de Godos, I., Acién, F.G., Molina, E., Banks, C. Heaven, S., 2013a. Fluid-dynamic characterization of real-scale raceway reactors for microalgae production. Biomass Bioenergy 54, 267-275. https://doi.org/ 10.1016/j.biombioe.2013.03.017.

Mendoza, J.L., Granados, M.R., de Godos, I., Acién, F.G., Molina, E., Heaven, S., Banks, C.J., 2013b. Oxygen transfer and evolution in microalgal culture in open raceways. Bioresour. Technol. 137, 188-195. https://doi.org/10.1016/ j.biortech.2013.03.127.

Min, M., Hu, B., Mohr, M.J., Shi, A., Ding, J., Sun, Y., Jiang, Y., Fu, Z., Griffith, R., Hussain, F., Mu, D., Nie, Y., Chen, P., Zhou, W., Ruan, R., 2014. Swine manurebased pilot-scale algal biomass production system for fuel production and wastewater treatment-a case study. Appl. Biochem. Biotechnol. 172, 1390-1406. https://doi.org/10.1007/s12010-013-0603-6.

Min, M., Wang, L., Li, Y., Mohr, M.J., Hu, B., Zhou, W., Chen, P., Ruan, R., 2011. Cultivating Chlorella sp. in a pilot-scale photobioreactor using centrate wastewater for microalgae biomass production and wastewater nutrient removal. Appl. Biochem. Biotechnol. 165, 123-137. https://doi.org/10.1007/s12010-0119238-7.

Molina-Grima, E., García Camacho, F., Acién Fernández, F.G., 1999. Production of EPA from phaeodactylum tricornutum. In: Cohen, Z. (Ed.), Chemicals from Microalgae. Taylor \& Francis Ltd, Londres, pp. 57-92.

Molina, E., Fernández, J., Acién, F.G., Chisti, Y., 2001. Tubular photobioreactor design for algal cultures. J. Biotechnol. 92, 113-131. https://doi.org/10.1016/S01681656(01)00353-4.

Morales-Amaral, M. del M., Gómez-Serrano, C., Acién, F.G., Fernández-Sevilla, J.M. Molina-Grima, E., 2015a. Outdoor production of Scenedesmus sp. in thin-layer and raceway reactors using centrate from anaerobic digestion as the sole nutrient source. Algal Res. 12, 99-108. https://doi.org/10.1016 j.algal.2015.08.020.

Morales-Amaral, M.D.M., Gómez-Serrano, C., Acién, F.G., Fernández-Sevilla, J.M., Molina-Grima, E., 2015b. Production of microalgae using centrate from anaerobic digestion as the nutrient source. Algal Res. 9, 297-305. https://doi.org/ 10.1016/j.algal.2015.03.018.

Muñoz, R., Alvarez, M.T., Muñoz, A., Terrazas, E., Guieysse, B., Mattiasson, B., 2006.
Sequential removal of heavy metals ions and organic pollutants using an algalbacterial consortium. Chemosphere 63, 903-911. https://doi.org/10.1016 j.chemosphere.2005.09.062.

Muñoz, R., Guieysse, B., 2006. Algal-bacterial processes for the treatment of haz ardous contaminants: a review. Water Res. 40, 2799-2815. https://doi.org/ 10.1016/j.watres.2006.06.011.

Osundeko, O., Pittman, J.K., 2014. Implications of sludge liquor addition for wastewater-based open pond cultivation of microalgae for biofuel generation and pollutant remediation. Bioresour. Technol. 152, 355-363. https://doi.org/ 10.1016/j.biortech.2013.11.035.

Pittman, J.K., Dean, A.P., Osundeko, O., 2011. The potential of sustainable algal biofuel production using wastewater resources. Bioresour. Technol. 102, 17-25. https://doi.org/10.1016/j.biortech.2010.06.035.

Posadas, E., García-Encina, P.A., Domínguez, A., Díaz, I., Becares, E., Blanco, S., Muñoz, R., 2014. Enclosed tubular and open algal-bacterial biofilm photobioreactors for carbon and nutrient removal from domestic wastewater. Ecol. Eng. 67, 156-164. https://doi.org/10.1016/j.ecoleng.2014.03.007.

Posadas, E., Morales, M.D.M., Gomez, C., Acién, F.G., Muñoz, R., 2015. Influence of pH and $\mathrm{CO} 2$ source on the performance of microalgae-based secondary domestic wastewater treatment in outdoors pilot raceways. Chem. Eng. J. 265, 239-248. https://doi.org/10.1016/j.cej.2014.12.059.

Rashid, U., Anwar, F., Moser, B.R., Knothe, G., 2008. Moringa oleifera oil: a possible source of biodiesel. Bioresour. Technol. 99, 8175-8179. https://doi.org/10.1016 j.biortech.2008.03.066.

Rawat, I., Ranjith Kumar, R., Mutanda, T., Bux, F., 2013. Biodiesel from microalgae: a critical evaluation from laboratory to large scale production. Appl. Energy 103, 444-467. https://doi.org/10.1016/j.apenergy.2012.10.004.

Rodríguez-Ruiz, J., Belarbi, E.-H., Sánchez, J.L.G., Alonso, D.L., 1998. Rapid simultaneous lipid extraction and transesterification for fatty acid analyses. Biotechnol. Tech. 12, 689-691. https://doi.org/10.1023/A:1008812904017.

Ruiz-Martinez, a., Martin Garcia, N., Romero, I., Seco, a., Ferrer, J., 2012. Microalgae cultivation in wastewater: nutrient removal from anaerobic membrane bioreactor effluent. Bioresour. Technol. 126, 247-253. https://doi.org/10.1016/ j.biortech.2012.09.022.

Sepúlveda, C., Acién, F.G., Gómez, C., Jiménez-Ruíz, N., Riquelme, C., MolinaGrima, E., 2015. Utilization of centrate for the production of the marine microalgae Nannochloropsis gaditana. Algal Res. 9, 107-116. https://doi.org/ 10.1016/j.algal.2015.03.004.

Sutherland, D.L., Howard-Williams, C., Turnbull, M.H., Broady, P.A., Craggs, R.J., 2015 Enhancing microalgal photosynthesis and productivity in wastewater treatment high rate algal ponds for biofuel production. Bioresour. Technol. 184, 222-229. https://doi.org/10.1016/j.biortech.2014.10.074.

Sydney, E.B., da Silva, T.E., Tokarski, A., Novak, A.C., de Carvalho, J.C. Woiciecohwski, A.L., Larroche, C., Soccol, C.R., 2011. Screening of microalgae with potential for biodiesel production and nutrient removal from treated domestic sewage. Appl. Energy 88, 3291-3294. https://doi.org/10.1016/ j.apenergy.2010.11.024.

Tan, X.-B., Yang, L.-B., Zhang, Y.-L., Zhao, F.-C., Chu, H.-Q., Guo, J., 2015. Chlorella pyrenoidosa cultivation in outdoors using the diluted anaerobically digested activated sludge. Bioresour. Technol. 198, 340-350. https://doi.org/10.1016/ j.biortech.2015.09.025.

Tzovenis, I., De Pauw, N., Sorgeloos, P., 2003. Optimisation of T-ISO biomass production rich in essential fatty acids: I. Effect of different light regimes on growth and biomass production. Aquaculture 216, 203-222. https://doi.org/10.1016/ S0044-8486(02)00374-5.

Xin, L., Hu, H., Ke, G., Sun, Y., 2010. Effects of different nitrogen and phosphorus concentrations on the growth, nutrient uptake, and lipid accumulation of a freshwater microalga Scenedesmus sp. Bioresour. Technol. 101, 5494-5500. https://doi.org/10.1016/j.biortech.2010.02.016.

Yamaberi, K., Takagi, M., Yoshida, T., 1998. Nitrogen depletion for intracellular triglyceride accumulation to enhance liquefaction yield of marine microalgal cells into a fuel oil. J Mar. Biotechnol, 6, 44-48.

Zhou, W., Chen, P., Min, M., Ma, X., Wang, J., Griffith, R., Hussain, F., Peng, P., Xie, Q. Li, Y., Shi, J., Meng, J., Ruan, R., 2014. Environment-enhancing algal biofue production using wastewaters. Renew. Sustain. Energy Rev. 36, 256-269. https://doi.org/10.1016/j.rser.2014.04.073.

Zhou, W., Li, Y., Min, M., Hu, B., Zhang, H., Ma, X., Li, L., Cheng, Y., Chen, P., Ruan, R., 2012a. Growing wastewater-born microalga Auxenochlorella protothecoides UMN280 on concentrated municipal wastewater for simultaneous nutrien removal and energy feedstock production. Appl. Energy 98, 433-440. https:// doi.org/10.1016/j.apenergy.2012.04.005.

Zhou, W., Min, M., Li, Y., Hu, B., Ma, X., Cheng, Y., Liu, Y., Chen, P., Ruan, R., 2012b. A hetero-photoautotrophic two-stage cultivation process to improve wastewater nutrient removal and enhance algal lipid accumulation. Bioresour. Technol. 110, 448-455. https://doi.org/10.1016/j.biortech.2012.01.063.

Zhu, L.-D., Hiltunen, E., 2016. Application of livestock waste compost to cultivate microalgae for bioproducts production: a feasible framework. Renew. Sustain. Energy Rev. 54, 1285-1290. https://doi.org/10.1016/j.rser.2015.10.093. 